\title{
Tissue distribution and acute toxicity of silver after single intravenous administration in mice: nano-specific and size-dependent effects
}

\author{
Camilla Recordati $^{{ }^{*}+}$ (D) Marcella De Maglie ${ }^{1,2+}$, Silvia Bianchessi ${ }^{1}$, Simona Argentiere ${ }^{1}$, Claudia Cella ${ }^{1,3}$, \\ Silvana Mattiello ${ }^{2}$, Francesco Cubadda ${ }^{4}$, Federica Aureli ${ }^{4}$, Marilena D'Amato ${ }^{4}$, Andrea Raggi ${ }^{4}$, Cristina Lenardi ${ }^{1,3,5}$, \\ Paolo Milani ${ }^{1,3,5}$ and Eugenio Scanziani ${ }^{1,2}$
}

\begin{abstract}
Background: Silver nanoparticles (AgNPs) are an important class of nanomaterials used as antimicrobial agents for a wide range of medical and industrial applications. However toxicity of AgNPs and impact of their physicochemical characteristics in in vivo models still need to be comprehensively characterized. The aim of this study was to investigate the effect of size and coating on tissue distribution and toxicity of AgNPs after intravenous administration in mice, and compare the results with those obtained after silver acetate administration.

Methods: Male CD-1(ICR) mice were intravenously injected with AgNPs of different sizes (10 nm, 40 nm, $100 \mathrm{~nm}$ ), citrate-or polyvinylpyrrolidone-coated, at a single dose of $10 \mathrm{mg} / \mathrm{kg}$ bw. An equivalent dose of silver ions was administered as silver acetate. Mice were euthanized $24 \mathrm{~h}$ after the treatment, and silver quantification by ICP-MS and histopathology were performed on spleen, liver, lungs, kidneys, brain, and blood.
\end{abstract}

Results: For all particle sizes, regardless of their coating, the highest silver concentrations were found in the spleen and liver, followed by lung, kidney, and brain. Silver concentrations were significantly higher in the spleen, lung, kidney, brain, and blood of mice treated with $10 \mathrm{~nm}$ AgNPs than those treated with larger particles. Relevant toxic effects (midzonal hepatocellular necrosis, gall bladder hemorrhage) were found in mice treated with $10 \mathrm{~nm}$ AgNPs, while in mice treated with $40 \mathrm{~nm}$ and $100 \mathrm{~nm}$ AgNPs lesions were milder or negligible, respectively. In mice treated with silver acetate, silver concentrations were significantly lower in the spleen and lung, and higher in the kidney than in mice treated with $10 \mathrm{~nm}$ AgNPs, and a different target organ of toxicity was identified (kidney).

Conclusions: Administration of the smallest $(10 \mathrm{~nm})$ nanoparticles resulted in enhanced silver tissue distribution and overt hepatobiliary toxicity compared to larger ones (40 and $100 \mathrm{~nm}$ ), while coating had no relevant impact. Distinct patterns of tissue distribution and toxicity were observed after silver acetate administration. It is concluded that if AgNPs become systemically available, they behave differently from ionic silver, exerting distinct and sizedependent effects, strictly related to the nanoparticulate form.

Keywords: Silver nanoparticles, Silver acetate, Dissolution, In vivo study, Mouse, Intravenous route, Tissue distribution, Toxicity, Hepatocellular necrosis, Hemorrhage

\footnotetext{
* Correspondence: camilla.recordati@gmail.com

${ }^{\dagger}$ Equal contributors

${ }^{1}$ Fondazione Filarete, 20139 Milan, Italy

Full list of author information is available at the end of the article
} 


\section{Background}

Silver nanoparticles (AgNPs) are an important class of nanomaterials characterized by sizes ranging approximately from 1 to $100 \mathrm{~nm}$ : these small dimensions result in a high surface area to volume ratio determining unique chemical, physical and biological properties different from those of bulk material with the same composition [1]. Nowadays, AgNPs are the most common nanomaterial found in consumer products (including cosmetics, textiles, food boxes, sprays), appliances (refrigerators, washing machines) and medical applications (wound dressings, medical devices, drug-delivery systems, bio-sensing and imaging methods) [2-5]. The widespread application of AgNPs is mainly related to the renowned antimicrobial activity of silver, whether ionic or nanoparticulate $[6,7]$. However, extensive use of AgNPs may lead to environmental contamination and human exposure by inhalation, dermal and oral routes, raising concerns about their potential environmental impact and toxicity [4].

The majority of toxicity studies on AgNPs have been performed on bacteria, cell lines, and non-mammalian animal species, with still comparatively limited information available from in vivo studies $[1,8]$. In vitro studies revealed distinct (but not necessarily mutually exclusive) mechanisms of toxicity of AgNPs, including 1) ROS generation, with subsequent oxidative stress; 2) interaction with cellular proteins and enzymes by binding to free thiol groups; and 3) mimicry of endogenous ions (e.g. calcium, sodium, or potassium) leading to ionoregulatory disturbances [1]. These mechanisms lead to cytokine production, cellular damage, and eventually apoptosis or necrosis. Numerous in vitro studies have demonstrated that the cytotoxic and genotoxic effects of AgNPs are size- and dose-dependent, as well as coating- and cell type-dependent [9-14].

In vivo studies in rodents (rats, mice, guinea pigs) and occasionally in non-rodents species (pigs) have been carried out, using different routes of exposure, in the attempt to characterize kinetics, tissue distribution and toxicity of AgNPs [15-26]. Compared to the general consensus of in vitro studies, the results of the in vivo studies are controversial regarding the onset of adverse effects after AgNPs administration. Some of these studies indicate that AgNPs may have toxic effects on liver, lung, intestine, nervous and immune systems, either after single or repeated administration, and following different routes of exposure [15-17, 22, 23, 26]. However, other studies found no relevant adverse effects [19-21, 24]. These contradictory results may depend on the high variability of the tested AgNPs, in terms of source (generated in the laboratory or commercially available materials), size, dispersion state, coating, and concentration (i.e. number of particles and silver mass). Also, the animal species, strain, sex, age, and the overall experimental design (dose, exposure time, end points for sampling) may have an impact on the outcome of the study [21].

With the effort to standardize and compare in vivo experiments, as well as to properly correlate nanoparticles' properties with their in vivo effects, a prior and rigorous physicochemical characterization of AgNPs is required [27]. In particular, the assessment of size, monodispersity, and aggregation is fundamental for a comprehensive understanding of their biological effects. However such measurements, albeit fundamental, are not sufficient for fully predicting nanotoxicological effects, likely because of effects related to the still poorly understood behavior of nanoparticles in the biological milieu. Indeed, AgNPs after injection readily interact with blood components (proteins, lipids, etc.), forming on their surface a biomolecular corona that influences the biological interactions of nanoparticles and cellular uptake [28]. In vivo toxicological studies are thus considered critical for correlating the physicochemical properties of nanoparticles with their effects in living systems [29]. However, only very few in vivo studies have been performed so far to evaluate the role of size and coating of AgNPs, and based on these studies tissue distribution and toxicity appeared to be consistently size-dependent, whereas the effect of coating was less obvious and only observed in the lung [21, 30-33]. In addition to influencing the formation of the biomolecular corona, size and coating are critical factors affecting the release of silver ions from AgNPs. There has been much debate in the literature regarding whether the adverse effects caused by AgNPs are mediated by the release of silver ions [34]. Although it is generally accepted that dissolution of AgNPs does account for at least a degree of toxicity observed under AgNP exposure, it appears that effects cannot be fully attributed to the measured dissolved fraction of silver especially for the smaller particles $(\leq 10 \mathrm{~nm})$, which proved to be more toxic than predicted on the basis of silver ion release $[35,36]$.

In view of the need to improve the understanding of the impact of physicochemical characteristics of AgNPs in in vivo models, the aim of this study was to investigate the effect of the size and coating on tissue distribution and toxicity of AgNPs and compare the results with those obtained after administration of silver ions, in the form of silver acetate. Since this study was not intended to mimic human exposure scenarios, to avoid limited systemic exposure due to the cellular barriers present in the skin, gastrointestinal tract and lungs, we used intravenous (IV) administration of AgNPs and ionic silver to evaluate their potential systemic toxicity. The study design included a thorough characterization of AgNPs suspensions before use, assessment of tissue distribution by measuring silver concentrations in blood and main organs, and histopathological examination to evaluate the presence of adverse effects and silver localization. 


\section{Results and discussion}

\section{Physicochemical characterization of silver nanoparticles} Commercial AgNPs with a nominal size of 10, 40 and $100 \mathrm{~nm}$ were tested in this study. Citrate (CT)- and polyvinylpyrrolidone (PVP)-coated AgNPs were investigated to probe the effect of surface stabilizing agents. Details provided by the manufacturer on the physico-chemical properties of the studied AgNPs are reported in Table 1. The particles were thoroughly characterized before the investigation of their toxicological effects in vivo and their accordance to manufacturer's specifications assessed. A rigorous characterization of the test dispersions is prerequisite to produce data that can help provide scientific answers to regulatory issues, which are impelling for a widely used nanomaterial type such as AgNPs.

Three different techniques were employed, namely Dynamic Light Scattering (DLS), UV-visible (UV-Vis) spectroscopy, and Transmission Electron Microscopy (TEM). First, the hydrodynamic diameter of the particles and their possible aggregation when suspended in the testing medium were evaluated by DLS. The results are summarized in Table 2. Monomodal distributions were observed for $40 \mathrm{~nm}$ and $100 \mathrm{~nm}$ AgNPs, coated with both CT and PVP. The $10 \mathrm{~nm}$ AgNP-CT and $10 \mathrm{~nm}$ AgNP-PVP suspensions showed multimodal distributions. In particular, the peaks at 18.1 and $19.6 \mathrm{~nm}$ were indicative of isolated nanoparticles in $10 \mathrm{~nm}$ AgNP-CT and $10 \mathrm{~nm}$ AgNP-PVP, respectively, while larger peaks in both samples suggested the possible presence of aggregates with variable dimensions. However, these large peaks were still detected by DLS even after filtration $(0.22 \mu \mathrm{m}$ pore size $)$, thus indicating their dynamic nature.

To further investigate the intrinsic features of the putative aggregates detected in $10 \mathrm{~nm}$ AgNPs, UV-Vis spectroscopy measurements were performed. AgNPs exhibit a characteristic absorbance maximum in the visible range due to the surface plasmon resonance (SPR) effect [37]. Notably, optical properties of AgNPs are closely related to their morphology, therefore UV-Vis spectroscopy is able to detect any change in size/shape as well as the presence of aggregates. The UV-Vis results are shown in Table 2. The correspondence between the optical properties given by the manufacturer and those measured in our laboratory appeared satisfactory; in particular, no decrease in the maximum absorbance value $\left(\mathrm{H}_{\max }\right)$ was observed, indicating absence of aggregates. Then, full absorbance spectra of all samples were considered (Fig. 1). The optical density in the 600-800 $\mathrm{nm}$ range, which is typical for aggregate absorption, was not detected in $10 \mathrm{~nm}$ AgNP-CT and $10 \mathrm{~nm}$ AgNP-PVP, further demonstrating that the presence of stable aggregates in these samples could be excluded [38].

Eventually, TEM analysis was performed to assess the shape and primary size distribution of tested AgNPs. All the tested AgNPs were spherical in shape (Fig. 2), and their Feret diameter distributions were in good accordance with data reported by the manufacturer $(p>0.05$ in all cases) (Table 2).

According to these analyses, both the $10 \mathrm{~nm}$ AgNPCT and the $10 \mathrm{~nm}$ AgNP-PVP gave questionable DLS results, since peaks by far larger than $10 \mathrm{~nm}$ were detected. Similar findings were recently reported for AgNPs with size lower than $20 \mathrm{~nm}$ and $15 \mathrm{~nm}$ [21]. Here, the absorbance spectra clearly confirmed the absence of any stable aggregate, since neither the $\mathrm{H}_{\max }$ decrease nor the absorbance in the $600-800 \mathrm{~nm}$ range were visible. TEM analysis further confirmed the absence of aggregates. Therefore, the large peaks detected in the DLS analyses of $10 \mathrm{~nm}$ AgNPs were ascribed to

Table 1 Main physicochemical properties of tested AgNPs provided by the manufacturer and reported in the datasheet

\begin{tabular}{|c|c|c|c|c|c|c|c|c|c|c|}
\hline \multirow{3}{*}{$\begin{array}{l}\text { Biopure }^{\mathrm{TM}} \text { Silver } \\
\text { nanoparticle }\end{array}$} & \multirow{3}{*}{ Lot $N^{\circ}$} & \multirow{3}{*}{$\begin{array}{l}\text { DLS } \\
\text { Mean } \\
\text { hydrodynamic } \\
\text { diameter } \\
(\mathrm{nm})\end{array}$} & \multicolumn{2}{|c|}{ UV-Vis } & \multicolumn{2}{|l|}{ TEM } & \multirow[b]{2}{*}{$\begin{array}{l}\text { Mass } \\
\text { concentration }\end{array}$} & \multirow[b]{2}{*}{$\begin{array}{l}\text { Particle } \\
\text { concentration }\end{array}$} & \multirow{3}{*}{ Solvent } & \multirow{3}{*}{$\begin{array}{l}\mathrm{pH} \text { of } \\
\text { solution }\end{array}$} \\
\hline & & & $\lambda \max$ & $\operatorname{H\operatorname {max}}$ & Diameter & $\begin{array}{l}\text { Variation } \\
\text { coefficient }\end{array}$ & & & & \\
\hline & & & $(\mathrm{nm})$ & (a.u.) & $\begin{array}{l}\text { (mean } \pm \\
\mathrm{SD})(\mathrm{nm})\end{array}$ & (\%) & $(\mathrm{mg} / \mathrm{ml})$ & $\begin{array}{l}\left(\mathrm{n}^{\circ} \text { of }\right. \\
\text { particles/ml) }\end{array}$ & & \\
\hline 10 nm AgNP-CT & DAG1542 & na & 388 & 164.9 & $8.8 \pm 1.7$ & 19.6 & 1.03 & $3.5^{*} 10^{14}$ & $\begin{array}{l}2.0 \mathrm{mM} \\
\text { citrate }\end{array}$ & 7.3 \\
\hline 10 nm AgNP-PVP & DAG1823A & 21.3 & 389 & 160.2 & $9.5 \pm 1.9$ & 7.5 & 1.1 & $2.2^{*} 10^{14}$ & $\begin{array}{l}\text { MilliQ } \\
\text { water }\end{array}$ & 6.9 \\
\hline $40 \mathrm{~nm}$ AgNP-CT & DAG1176 & 53.7 & 411 & 151.1 & $40.6 \pm 3.0$ & 7.0 & 1.12 & $2.7^{*} 10^{12}$ & $\begin{array}{l}2.0 \mathrm{mM} \\
\text { citrate }\end{array}$ & 7.6 \\
\hline 40 nm AgNP-PVP & DAG1391 & 49.3 & 411 & 148.2 & $40.7 \pm 4.1$ & 20.2 & 1.1 & $2.7^{*} 10^{12}$ & $\begin{array}{l}\text { MilliQ } \\
\text { water }\end{array}$ & 6.7 \\
\hline 100 nm AgNP-CT & DAG1186 & 99.8 & 495 & 49.2 & $99.4 \pm 7.0$ & 10.0 & 1.0 & $1.9^{*} 10^{11}$ & $\begin{array}{l}2.0 \mathrm{mM} \\
\text { citrate }\end{array}$ & 7.3 \\
\hline 100 nm AgNP-PVP & DAG1189 & 117.0 & 492 & 48.2 & $99.0 \pm 5.7$ & 5.8 & 1.07 & $1.9^{*} 10^{11}$ & $\begin{array}{l}\text { MilliQ } \\
\text { water }\end{array}$ & 5.9 \\
\hline
\end{tabular}


Table 2 Physicochemical characterization of tested AgNPs. The main findings in AgNPs characterization are reported for each tested sample. For DLS analyses, the mean size of AgNPs is expressed in terms of hydrodynamic diameter, however this parameter is fully informative only for samples with monomodal distributions. Accordingly, the maximum intensity peaks were also reported to describe more comprehensively samples having multimodal distributions (i.e. $10 \mathrm{~nm}$ AgNP-CT and $10 \mathrm{~nm}$ AgNP-PVP). The pdl provides a measure of particles uniformity. For UV-Vis analyses, the maximum wavelength $\left(\lambda_{\max }\right.$ i.e. the wavelength corresponding to the highest absorbance of AgNPs) and the maximum absorbance value $\left(H_{\max }\right)$ are reported. The $\lambda_{\max }$ and $H_{\max }$ values were expressed in nanometer ( $\mathrm{nm}$ ) and arbitrary units (a.u.), respectively. Finally, AgNPs size distributions expressed as Feret diameter (mean $\pm \mathrm{SD}, \mathrm{nm}$ ) and variation coefficient (\%) were obtained from TEM analysis

\begin{tabular}{|c|c|c|c|c|c|c|c|c|}
\hline \multirow{2}{*}{$\begin{array}{l}\text { Biopure }{ }^{\mathrm{TM}} \text { Silver } \\
\text { nanoparticle }\end{array}$} & \multirow[t]{2}{*}{ Lot $N^{\circ}$} & \multicolumn{3}{|l|}{ DLS } & \multicolumn{2}{|c|}{ UV-Vis } & \multicolumn{2}{|l|}{ TEM } \\
\hline & & $\begin{array}{l}\text { Mean hydrodynamic diameter } \\
(\mathrm{nm})\end{array}$ & $\begin{array}{l}\text { Max intensity peaks } \\
(\mathrm{nm})\end{array}$ & $\mathrm{pdl}$ & $\begin{array}{l}\lambda \max \\
(\mathrm{nm})\end{array}$ & $\begin{array}{l}\operatorname{Hmax} \\
\text { (a.u.) }\end{array}$ & $\begin{array}{l}\text { Diameter } \\
(\text { mean } \pm S D, n m)\end{array}$ & $\begin{array}{l}\text { Variation coefficient } \\
\text { (\%) }\end{array}$ \\
\hline 10 nm AgNP-CT & DAG1542 & $\mathrm{np}$ & $18.1-4046$ & 0.258 & 392 & 163.5 & $8.4 \pm 1.5$ & 25.4 \\
\hline 10 nm AgNP-PVP & DAG1823A & $\mathrm{np}$ & $19.6-111-4292$ & 0.343 & 389 & 163.6 & $10.8 \pm 2.6$ & 24.0 \\
\hline 40 nm AgNP-CT & DAG1176 & 40.1 & 49.8 & 0.213 & 412 & 152.6 & $39.3 \pm 4.8$ & 12.3 \\
\hline 40 nm AgNP-PVP & DAG1391 & 51.8 & 67.6 & 0.251 & 410 & 145.7 & $40.3 \pm 5.6$ & 13.9 \\
\hline 100 nm AgNP-CT & DAG1186 & 87.6 & 102.9 & 0.148 & 490 & 45.1 & $107.7 \pm 10.5$ & 9.8 \\
\hline 100 nm AgNP-PVP & DAG1189 & 104.1 & 119.4 & 0.124 & 491 & 46.8 & $105.5 \pm 10.9$ & 10.4 \\
\hline
\end{tabular}

$\mathrm{Np}$ not provided for samples with multimodal distributions

dynamic aggregates, which are unstable and do not represent a problem for in vivo experiments. In conclusion, the characterization by DLS, UV-Vis spectroscopy, and TEM of stock AgNPs suspensions confirmed the particle size certified by the manufacturer and their suitability for in vivo administration.

\section{Dissolution of silver nanoparticles in mouse serum}

The presence of ionic silver in the stock suspensions of CT-coated AgNPs as well as AgNPs dissolution upon interaction with mouse serum was investigated by filtration on membranes with a pore size allowing discrimination of ionic silver from AgNPs. The percentage of ionic silver in the original stock suspensions was found to be negligible $(0.002 \%, 0.001 \%, 0.001 \%$ of total silver for 10, 40 and $100 \mathrm{~nm}$ AgNPs, respectively). Timedependent dissolution of AgNPs in simulated biological conditions is shown in Table 3. As expected, dissolution was greater for smaller particles and increased with time; however even for $10 \mathrm{~nm}$-sized particles at $24 \mathrm{~h}$, the

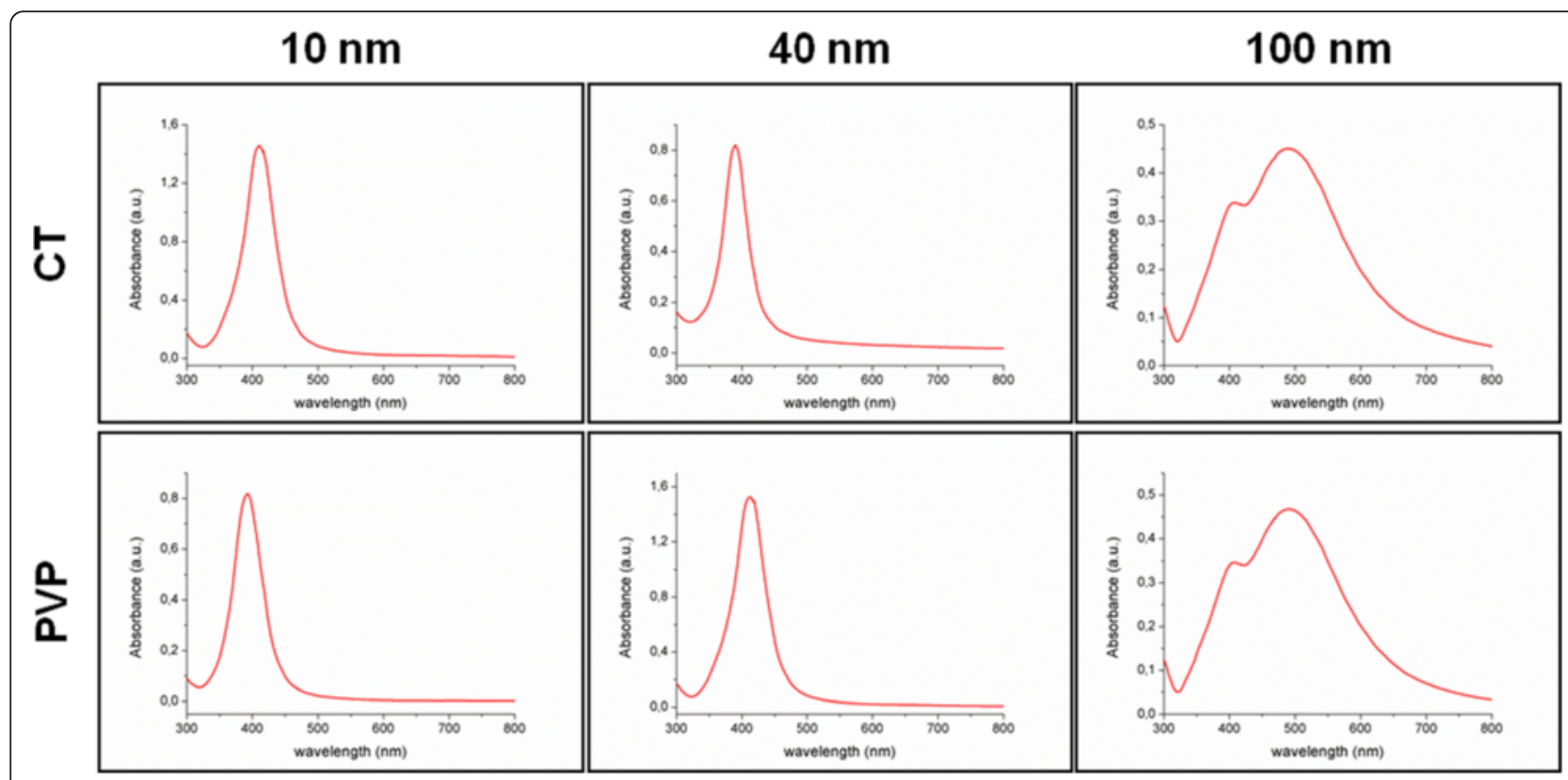

Fig. 1 Particle characterization by UV-Vis spectroscopy: full absorbance spectra of the tested silver nanoparticles. The optical density in the $600-800 \mathrm{~nm}$ range, which is typical for aggregate absorption, was not detected in any of tested AgNPs, indicating the absence of stable aggregates in these samples 


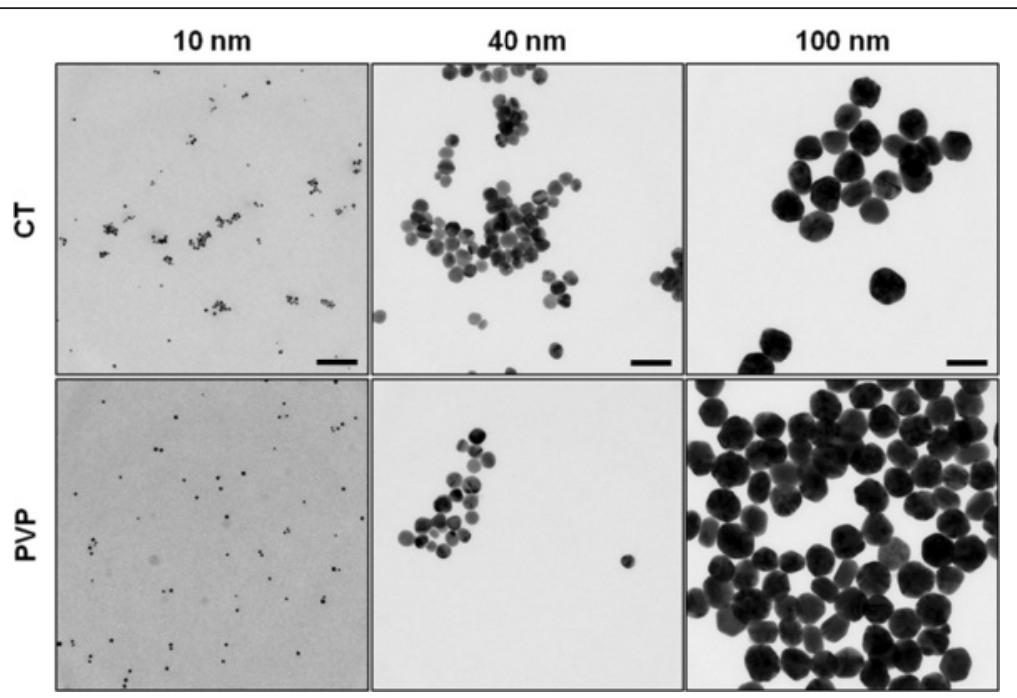

Fig. 2 TEM of tested silver nanoparticles. Representative transmission electron micrographs of 10, 40, and $100 \mathrm{~nm}$ AgNPs, CT- and PVP-coated. All purchased particles were spherical in shape, and no stable aggregates were visible (scale bar $=100 \mathrm{~nm}$ )

percentage of ionic silver was found to be exceedingly low $(0.005 \%)$.

The low dissolution of AgNPs when incubated in mouse serum is in accordance with other studies, which put forward that following introduction into a physiological environment the ability of AgNPs to release $\mathrm{Ag}^{+}$is likely inhibited due to the formation of the protein corona [39]. Interaction of protein thiol groups with the charged surface of AgNPs in a medium with a high ionic strength is at the basis of the sulfidation process that leads to an extensive decrease of the dissolution rate in vitro, causing also the formation of nanobridges between particles, and has the potential to stabilize them in vivo [40]. Formation of the protein corona decreases the extracellular dissolution of AgNPs leading to cellular uptake of particles, which may lose the corona after internalization resulting in an exacerbated release of $\mathrm{Ag}$ ions and toxicity [39].

Dissolved silver ions are likely to immediately react with chlorine in serum to form $\mathrm{AgCl}$ [41]. On the other hand, it cannot be ruled out that a minor part of the released silver ions might have been complexed with high affinity $\mathrm{S}$-containing proteins and thus been excluded by the membrane used, leading to a possible underestimation of the level of released $\mathrm{Ag}^{+}$[42]. However, even though the method used for studying particle dissolution may have not provided an entirely accurate measure of ionic silver formation in physiological conditions - all available methods have some limitations in this respect [43] - it clearly shows that extracellular dissolution of the AgNPs used in this study is very limited and animals dosed with AgNPs were internally exposed to particulate and not ionic silver.

\section{In vivo study}

Mice were intravenously (IV) injected with CT- or PVPcoated AgNPs of different sizes at a single dose of $10 \mathrm{mg} / \mathrm{kg}$ body weight (bw). For comparison, a group was treated with silver acetate (AgAc), used as source of silver ions, at a dose of $15.5 \mathrm{mg} / \mathrm{kg} \mathrm{bw}$, containing the equivalent dose of $10 \mathrm{mg} \mathrm{Ag} / \mathrm{kg}$ bw. The body weight of each mouse was measured before treatment and at sacrifice. Mice were euthanized $24 \mathrm{~h}$ after the treatment, and blood and organs were collected for silver quantification and histological examination.

Table 3 Time dependent dissolution of AgNPs in simulated biological conditions. Results for ionic silver are expressed as percentage of total silver measured in the stock suspensions

\begin{tabular}{lllll}
\hline Biopure ${ }^{\text {TM }}$ Silver nanoparticle & $5 \mathrm{~min}$ & $10 \mathrm{~min}$ & $60 \mathrm{~min}$ & $24 \mathrm{~h}$ \\
\hline $10 \mathrm{~nm}$ AgNP-CT & $0.377^{*} 10^{-3}$ & $0.510^{*} 10^{-3}$ & $0.937^{*} 10^{-3}$ & $5.010^{*} 10^{-3}$ \\
$40 \mathrm{~nm}$ AgNP-CT & $0.049^{*} 10^{-3}$ & $0.075^{*} 10^{-3}$ & $0.176^{*} 10^{-3}$ & $1.235^{*} 10^{-3}$ \\
$100 \mathrm{~nm}$ AgNP-CT & $0.005^{*} 10^{-3}$ & $0.016^{*} 10^{-3}$ & $0.038^{*} 10^{-3}$ & $0.366^{*} 10^{-3}$ \\
\hline
\end{tabular}


In this study, the IV route of administration was selected in order to avoid the variability in absorption from the different exposure sites and identify the potential target organs for distribution and toxicity of particles of different size and coating as well as of ionic silver. Although IV administration is not considered a relevant route of exposure to AgNPs for the consumer, this route of exposure can provide valuable information about the in vivo behavior of AgNPs crossing the primary barriers (skin, lung, gastrointestinal tract) and entering blood circulation, or administered for clinical purposes (e.g. intravascular medical devices, wound dressings, imaging, drug delivery) [44-47]. In many studies silver was detected in the main organs after exposure to AgNPs by different routes $[15,16,21,25,48,49]$, but only few studies investigated the presence of silver particles in tissues after oral exposure in rats [21, 48]. Loeschner et al. [48] found silver granules by using TEM in the same size range of administered AgNPs in the intestine (basal lamina, macrophages, connective tissue of submucosa), but not in the liver, after oral administration of $14 \mathrm{~nm}$ AgNPs and AgAc (9 mg/kg b.w. of silver. Another study [21], by using single particle ICP-MS, revealed the presence of NPs in the examined organs (gastrointestinal tract, liver, spleen, lungs) after oral administration of 15-20 nm AgNPs (90 mg/kg b.w) and $\mathrm{AgNO}_{3}(9 \mathrm{mg} /$ $\mathrm{kg})$. In both studies, nanoparticles were found also in the group treated with $\mathrm{Ag}^{+}$, indicating that nanoparticles can be formed in vivo from soluble silver. Even though there is still little information on the ability of AgNPs to be absorbed, and distribute systemically after dermal application, inhalation, or ingestion, a definite conclusion about the complete dissolution of AgNPs before reaching the blood circulation or within the blood cannot be drawn as well, leaving open the question about the potential effects of AgNPs in case they enter (even partially) blood circulation.

A dose of $10 \mathrm{mg} / \mathrm{kg}$ bw was chosen since it was in the range of doses used in previous IV studies without eliciting relevant adverse effects in animals [22, 23, 30, $31,50]$. A dose of $10 \mathrm{mg} / \mathrm{kg}$ bw in mice is equivalent to a human dose of $0.81 \mathrm{mg} / \mathrm{kg}$ bw, corresponding to approximately $50 \mathrm{mg}$ for a human of $60 \mathrm{~kg}$, according to guidelines for dose translation from animals to humans [51].

\section{Animal behavior, body and organ weights}

Immediately after administration of AgNPs and AgAc and during the following hours, all mice appeared healthy and no abnormal behavior was observed. However, $24 \mathrm{~h}$ after the treatment two mice (one mouse treated with $10 \mathrm{~nm}$ AgNP-CT and another one treated with $10 \mathrm{~nm}$ AgNP-PVP) were found dead. Complications related to the injection procedure or formation of large aggregates after administration were reasonably ruled out given the delayed onset of mortality and results of later histopathological evaluation (i.e. absence of thromboembolic lesions associated with silver aggregates). At sacrifice, no significant differences in body weight gain and organ weights were recorded between CT- and PVP-coated AgNPs of the same size (Additional file 1: Table S1). In mice treated with $10 \mathrm{~nm} \mathrm{AgNPs} \mathrm{a}$ significant difference in percentage of weight loss and relative spleen weight were observed compared to control and 40 and $100 \mathrm{~nm}$ AgNP-treated mice (Table 4). No other significant differences were observed in relative organ weights between treated and control mice.

\section{Tissue distribution and localization of silver}

Distribution and localization of silver in the different organs $24 \mathrm{~h}$ after IV exposure to CT- and PVP-coated AgNPs of three different sizes, and AgAc, were evaluated using two distinct but complementary approaches, i.e. inductively coupled plasma mass spectrometer (ICP-MS) and autometallography (AMG) staining. ICP-MS was used to quantitatively measure the total silver concentration in spleen, liver, lung, kidney, brain, and blood, while AMG was used to qualitatively assess silver localization within the sampled organs.

In the control group, silver was present at background levels as shown by ICP-MS data for the examined organs (Additional file 1: Table S2). In the treated animals, at $24 \mathrm{~h}$ after administration the silver concentration in blood was drastically reduced in all groups compared to the peak concentrations expected on the basis of the administered dose, in agreement with

Table 4 Body weight gain and relative organ weight (\%) after IV administration of $10 \mathrm{mg}$ silver/kg. Data are expressed as means \pm SD

\begin{tabular}{llllllll}
\hline Group & $\mathrm{n}$ & Body weight gain & Spleen & Liver & Lung & Kidney \\
\hline Control & 3 & $-3.3 \pm 5$ & $0.45 \pm 0.1$ & $6.61 \pm 0.8$ & $0.66 \pm 0.0$ & $1.80 \pm 0.2$ & $1.77 \pm 0.1$ \\
$10 \mathrm{~nm} \mathrm{AgNP}$ & 6 & $-12.1 \pm 4.1^{*}$ & $0.67 \pm 0.0^{*}$ & $7.23 \pm 1.1$ & $0.76 \pm 0.1$ & $1.75 \pm 0.1$ & $1.81 \pm 0.2$ \\
$40 \mathrm{~nm} \mathrm{AgNP}$ & 6 & $-1.3 \pm 2.8^{++}$ & $0.54 \pm 0.1^{++}$ & $6.87 \pm 0.6$ & $0.65 \pm 0.1$ & $1.79 \pm 0.3$ & $1.78 \pm 0.1$ \\
$100 \mathrm{~nm} \mathrm{AgNP}$ & 6 & $-0.1 \pm 5.0^{++}$ & $0.40 \pm 0.1^{++}$ & $6.97 \pm 0.2$ & $0.63 \pm 0.1$ & $1.80 \pm 0.1$ & $1.65 \pm 0.1$ \\
AgAc & 3 & $-6.3 \pm 3.3$ & $0.47 \pm 0.0^{+}$ & $6.99 \pm 0.0$ & $0.80 \pm 0.1$ & $1.92 \pm 0.2$ & $1.78 \pm 0.2$ \\
\hline
\end{tabular}

${ }^{*} p<0.05$ vs Control; $+p<0.05++p<0.01$ vs $10 \mathrm{~nm} \mathrm{AgNP}$ 
previous studies of kinetics performed after one single IV administration of $120 \mathrm{mg} / \mathrm{kg}$ of $15 \mathrm{~nm}$ AgNPs [22] and $0.8 \mathrm{mg} / \mathrm{kg}$ of 20, 80, and $110 \mathrm{~nm} \mathrm{AgNPs} \mathrm{[30].} \mathrm{In}$ the blood of $10 \mathrm{~nm}$ AgNPs-treated mice silver was approximately 1.5 times and 3.5 times higher than in mice treated with $40 \mathrm{~nm}$ and $100 \mathrm{~nm}$ AgNPs, respectively (Additional file 1: Table S2). Since previous studies demonstrated a rapide decline (minutes to few hours) of silver blood levels after IV injection of AgNPs regardless of nanoparticle size [22, 30, 50], the greater silver concentration of $10 \mathrm{~nm}$ AgNPs-treated mice $24 \mathrm{~h}$ after exposure might indicate an increased and earlier redistribution of silver from organs to blood in the case of $10 \mathrm{~nm}$ AgNPs compared to larger ones. The results obtained for $10 \mathrm{~nm}$ AgNPs are in agreement with those of a IV study on CT-coated AgNPs having a similar size $(8 \mathrm{~nm})$, administered to rats at the same dose of the present study $(10 \mathrm{mg} / \mathrm{kg}$ bw); after an initial decrease (up to $4 \mathrm{~h}$ post injection) blood silver levels increased again and did not decrease during the experimental period until $96 \mathrm{~h}$ [50].

For all particle sizes, regardless of their coating, the highest silver concentrations were found in the spleen and liver, followed by lung, kidney and brain (Fig. 3, and Additional file 1: Figure S1). These results are in line with previous studies that investigated tissue distribution of AgNPs $24 \mathrm{~h}$ after IV administration [22, 30, 50]. When considering the percentage of the administered silver dose recovered after administration, for all tested AgNPs approximately $40 \%$ of the administered dose was found in the liver, which resulted to be the main target organ of silver distribution, followed by spleen, lung, kidney, and brain (Table 5). Most of the silver that reaches the blood is filtered by the liver and excreted into the bile [50], while the remaining circulating particles distributed to organs containing large numbers of phagocytic cells, such as liver, spleen, and lung, which are devoted to clearing foreign body particles from the circulating blood. The role of macrophages in general, and Kupffer cells in particular, in clearance and accumulation of nanoparticles was the same observed after intravenous administration of other metallic nanoparticles (e.g. gold NPs) [52, 53].

With exception of the liver, where similar silver concentrations were identified regardless of the source of administered silver (AgNP or silver ions), in the other examined organs silver concentrations were higher in mice treated with $10 \mathrm{~nm}$ AgNPs (including both CTand PVP-coated particles) than in mice treated with larger particles $(40 \mathrm{~nm}, 100 \mathrm{~nm})$, and concentrations decreased with increasing size of AgNPs. Since the silver concentrations found in the brain and kidney were comparable or lower than those found in the blood, silver contribution of residual blood contained in these organs cannot be completely ruled out.

As regards the role of coating on silver tissue distribution, no significant differences were found between CT- and PVP-coated AgNPs of the same size, in line with previous studies [21]. However, Principal Component Analysis (PCA) highlighted a trend of CT-coated $10 \mathrm{~nm}$ AgNPs to cluster separately from PVP-coated $10 \mathrm{~nm}$ AgNPs (right side of the first Principal Component, PC1) likely due to the higher silver concentrations of the $10 \mathrm{~nm} \mathrm{AgNP-CT}$ in spleen, lungs, liver, and, to a lesser extent, in kidneys compared to $10 \mathrm{~nm}$ AgNP-PVP (Additional file 1: Figure S2). PCA thus revealed that the coating might have a potential effect of on tissue distribution at least for the smallest $(10 \mathrm{~nm})$ AgNPs.

Silver localization within organs was evaluated histologically. In H\&E stained sections intracytoplasmic

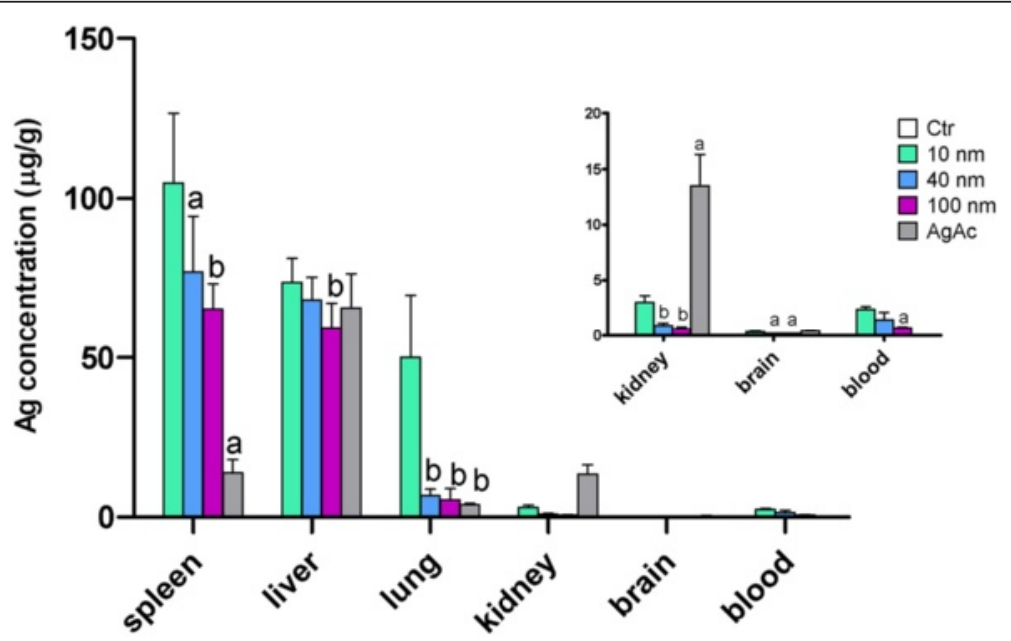

Fig. 3 Silver tissue concentration after IV administration of AgNPs and AgAc in mice. Data are expressed as means \pm SD. Statistical significance: $a=p<0.05$; $\mathrm{b}=p<0.01$ vs $10 \mathrm{~nm}$ 
Table 5 Percentage of recovered silver dose in mice after IV administration of $10 \mathrm{mg}$ silver $/ \mathrm{kg}$. Data are expressed as means \pm SD

\begin{tabular}{lllllll}
\hline Group & $\mathrm{n}$ & Spleen & Liver & Lung & Kidney & Brain \\
\hline $10 \mathrm{~nm}$ AgNP-CT & 3 & $6.6 \pm 1.2$ & $52.0 \pm 4.7$ & $4.2 \pm 1.1$ & $0.5 \pm 0.1$ & $0.056 \pm 0.015$ \\
$10 \mathrm{~nm}$ AgNP-PVP & 3 & $5.3 \pm 1.0$ & $41.1 \pm 2.3$ & $1.5 \pm 1.2$ & $0.4 \pm 0.1$ & $0.049 \pm 0.016$ \\
$40 \mathrm{~nm}$ AgNP-CT & 3 & $3.6 \pm 1.1$ & $46.1 \pm 2.5$ & $0.5 \pm 0.1$ & $0.1 \pm 0.1$ & $0.037 \pm 0.007$ \\
$40 \mathrm{~nm}$ AgNP-PVP & 3 & $3.1 \pm 1.1$ & $45.5 \pm 1.9$ & $0.3 \pm 0.1$ & $0.2 \pm 0.0$ & $0.035 \pm 0.009$ \\
$100 \mathrm{~nm}$ AgNP-CT & 3 & $2.7 \pm 0.4$ & $36.7 \pm 0,3$ & $0.5 \pm 0.1$ & $0.1 \pm 0.0$ & $0.029 \pm 0.004$ \\
$100 \mathrm{~nm}$ AgNP-PVP & 3 & $2.5 \pm 0.6$ & $45.7 \pm 1.1$ & $0.2 \pm 0.0$ & $0.1 \pm 0.0$ & $0.028 \pm 0.003$ \\
AgAc & 3 & $0.6 \pm 0.2$ & $42.6 \pm 4.5$ & $0.3 \pm 0.1$ & $2.4 \pm 0.6$ & $0.064 \pm 0.011$ \\
\hline
\end{tabular}

black granular pigment was multifocally (and often barely) visible in the liver (along the sinusoids), spleen (marginal zone and red pulp), and lungs (alveolar septa) of all AgNP-treated mice, but not in AgActreated mice (Additional file 1: Figure S3).
The tissue localization of silver was better detailed after AMG staining (Fig. 4), which enhances the silver present within the tissues, providing a rapid, costeffective histochemical means of detecting the distribution of silver within organs [54]. In AgNP-treated mice,

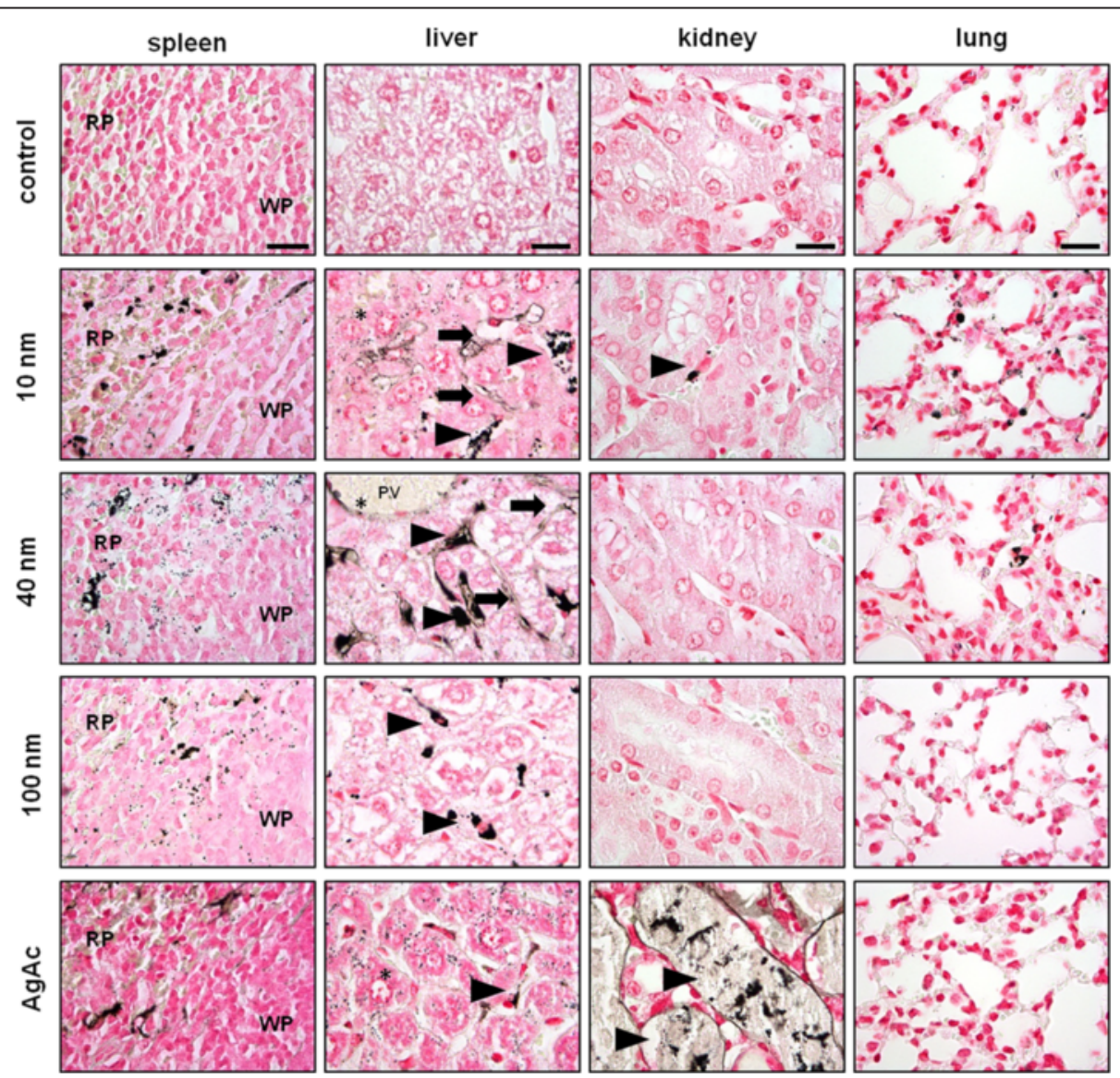

Fig. 4 Histological evaluation of silver tissue localization by AMG. Representative images of spleen, liver, kidney, and lung (scale bar = $20 \mu \mathrm{m}$ ), from vehicle- (control), AgNP (10 nm, $40 \mathrm{~nm}, 100 \mathrm{~nm}$ ), and AgAc-treated mice. In the spleen, silver was localized within the cytoplasm of macrophages in the marginal zone of the white pulp (WP) and in the red pulp (RP). In the liver, the cellular localization of silver varied depending on the size of the AgNPs. In $10 \mathrm{~nm}$ AgNP-treated mice, silver was present in the cytoplasm of Kupffer cells (arrowhead), sinusoidal endothelial cells (arrow) and hepatocytes (*). In $40 \mathrm{~nm}$ AgNPs-treated mice, silver was localized in the cytoplasm of portal endothelial cells (*), sinusoidal endothelial cells (arrow) and Kupffer cells (arrowhead). In $100 \mathrm{~nm}$ AgNPs-treated mice, most of silver was concentrated in the cytoplasm of Kupffer cells (arrowhead). In AgAc-treated mice, silver was present in the cytoplasm of hepatocytes $\left({ }^{*}\right)$, and Kupffer cells (arrowhead). In the kidney, occasional silver-containing cells were observed in the renal interstitium of $10 \mathrm{~nm}$ AgNP treated-mice (arrowhead), and large amounts of silver were identified in necrotic tubules of AgAc-treated mice (arrowhead). In the lung, scattered silver-containing cells were found in the alveolar septa of $10 \mathrm{~nm}$ and $40 \mathrm{~nm}$ AgNP-treated mice 
regardless of the particle size and coating, the organs showing the greatest silver accumulation were the spleen and liver in agreement with the results of total silver quantification obtained by ICP-MS. Occasionally, enhanced silver clusters were found in the lung and occasionally in the kidney (mainly in $10 \mathrm{~nm}$ AgNPs-treated mice), and none in the brain. In the spleen, silver was localized within the cytoplasm of macrophages in the marginal zone of the white pulp and in the red pulp, and occasionally within splenic endothelial cells. In the liver most of the silver was found in the cytoplasm of Kupffer cells along the sinusoids, and occasionally within sinusoidal and portal endothelial cells, and more rarely within hepatocytes, in accordance with previous studies [23, 31, 55]. A sort of size-dependent pattern of silver distribution in the liver was observed, suggesting that silver uptake by Kupffer cells is almost exclusive after administration of $100 \mathrm{~nm}$ AgNPs, while administration of $10 \mathrm{~nm}$ and $40 \mathrm{~nm}$ AgNPs resulted in silver uptake also by endothelial cells, and hepatocytes, in addition to Kupffer cells. Only occasionally, the silver was identified in the gall bladder of $10 \mathrm{~nm}$ AgNP-treated mice (within gall bladder epithelial cells and endothelial cells of blood vessels). In the lung, scattered silver containing cells were found in the alveolar septa, either within the capillaries or the interstitium. In the kidney, only in mice treated with $10 \mathrm{~nm}$ AgNPs there were occasional silver-containing cells in the glomerular tufts, and renal interstitium, morphologically consistent with circulating leukocytes (monocytes) that were also occasionally observed in the other examined organs. No enhanced silver clusters were identified in the brain sections of treated mice. This lack of histological identification of silver in the brain is consistent with the very small concentrations of silver detected in this organ by ICP-MS.

In mice treated with AgAc silver concentrations determined by ICP-MS were similar in the liver and brain, but significantly lower in the spleen and lung, and higher in the kidney compared to mice treated with $10 \mathrm{~nm}$ AgNPs (Fig. 3). Differently from AgNP-treated mice, no black granular deposits (reminiscent of silver) were found throughout the examined tissues stained with H\&E. In AMG stained sections, silver enhanced clusters were identified in the liver (within Kupffer cells and hepatocytes), spleen (marginal zone and red pulp), and kidney (at level of degenerated/necrotic tubules) (Fig. 4). No silver was identified in the lung and brain. Organs from AgAc-treated mice showed higher values than those from the control and AgNP-treated mice on PC2, due to the higher silver concentration in the kidney (Additional file 1: Figure S2). Overall these results suggest that silver ions have a different biodistribution pattern, and likely also of cell uptake, and excretion (i.e. enhanced role of renal excretion in addition to biliary excretion) compared to nanoparticles. This difference in kinetics was reflected also by the identification of distinct target organ of toxicity for silver ions and AgNPs, as discussed below.

Immunostaining of sections with IBA1 (a panmacrophage marker) further confirmed that most of silver-containing aggregates were present within the cytoplasm of Kupffer cells in the liver, in all AgNPtreated groups (Fig. 5). The amount and size of silvercontaining aggregates within macrophages decreased with decreasing size of AgNPs. In $10 \mathrm{~nm}$ AgNPstreated mice only scattered and very small aggregates were found throughout the liver, while no visible silver-containing aggregates were found in the liver of AgAc treated mice, despite the identification of silver by AMG staining within Kupffer cells and hepatocytes. This result may suggest a different intracellular behavior of silver depending on its form and size.

Since ICP-MS does not provide information about the soluble or particulate form of silver detected within the tissue, it is not possible to know whether the silvercontaining aggregates identified histologically in this study were composed of silver nanoparticles or silver salts formed upon interaction of silver ions with sulphur and selenium, as previously described in the intestine of rats following oral administration of AgNPs and AgAc [48], or in the skin of patients with argyria [56, 57]. Additional analyses, e.g. employing TEM with energy dispersive $\mathrm{x}$-ray spectroscopy (EDX), and Single Particle ICP-MS (not for the $10 \mathrm{~nm}$ AgNPs, which are below the size detection limit of the technique) should be taken into consideration in future studies, to assess the composition and subcellular localization of silver within tissues, allowing to better understand the intracellular fate of AgNPs and/or silver ions.

\section{Toxicity}

Two mice out of six were found dead $24 \mathrm{~h}$ after treatment with $10 \mathrm{~nm}$ AgNPs. No relevant gross changes were observed in the examined mice, except for a moderate splenomegaly in mice treated with $10 \mathrm{~nm}$ AgNPs. Histological AgNP-related lesions were observed in the spleen, liver, and gall bladder of AgNP-treated mice (Fig. 6). No relevant differences were found between CT- and PVP-coated particles of the same size. Overall the prevalence and severity of lesions (in particular those involving liver and gall bladder) were size-dependent, with mice treated with $10 \mathrm{~nm}$ AgNPs most frequently and severely affected compared to $40 \mathrm{~nm}$ and $100 \mathrm{~nm}$ AgNP-treated mice that had milder or negligible lesions, respectively (Tables 6 and 7). Splenic hyperemia was present in all mice treated with AgNPs, but only in mice treated with $10 \mathrm{~nm}$-sized particles it was particularly pronounced, and thus likely responsible for inducing 


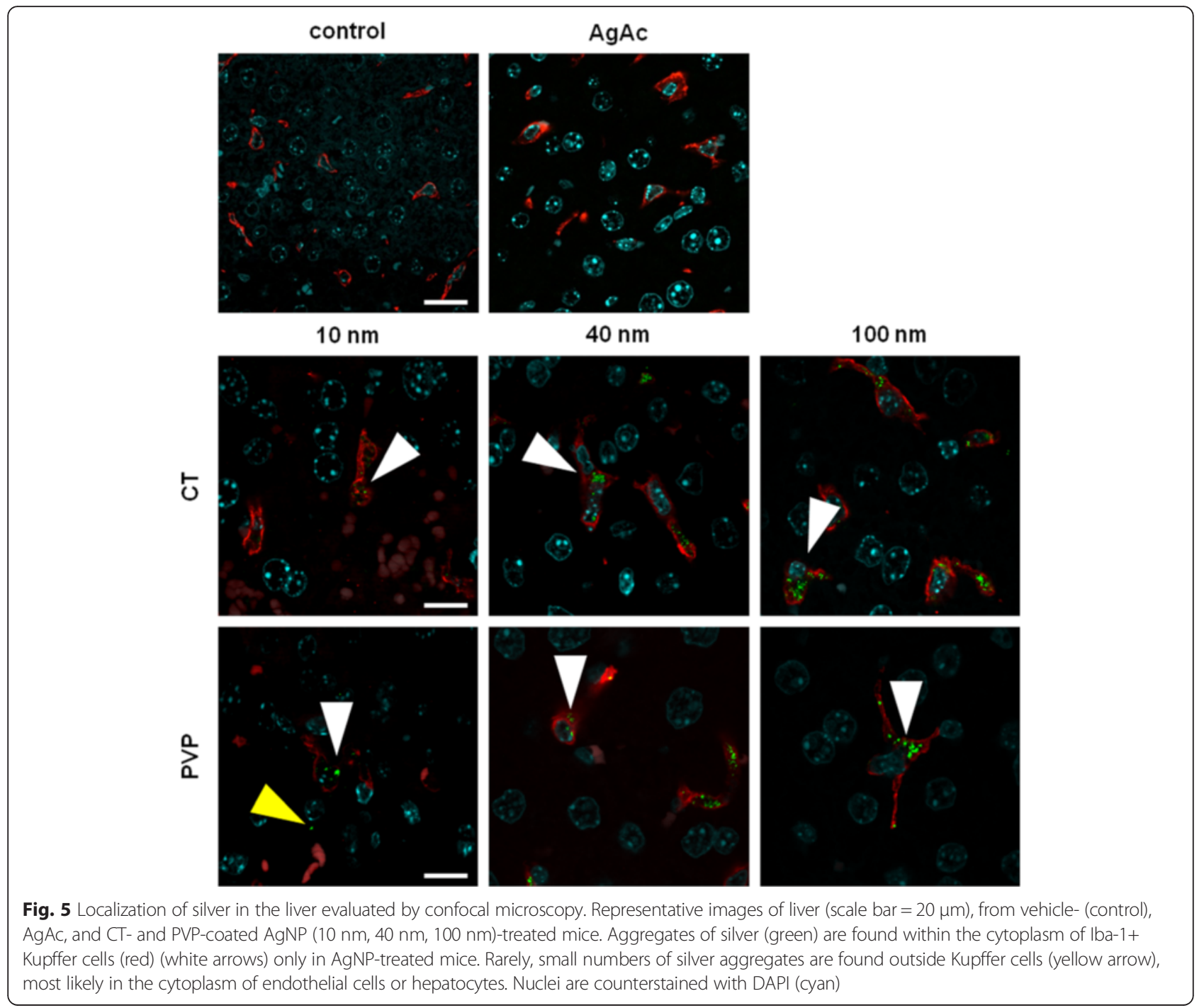

splenomegaly, as well as the increased relative spleen weight observed in this group. Mice treated with $10 \mathrm{~nm}$ AgNPs were affected by diffuse and severe midzonal hepatocellular necrosis and hemorrhage, multifocal peribiliary microhemorrhages, occasional portal vein endothelial damage (i.e. endothelial sloughing, subendothelial hemorrhages, intraluminal fibrin thrombi) (Additional file 1: Figure S4), and diffuse mural and intraluminal hemorrhage of the gall bladder. Among mice treated with $40 \mathrm{~nm}$ AgNPs only one out of six had early periportal coagulative necrosis, scattered hepatic single cell necrosis, and gall bladder severe mural and intraluminal gall bladder hemorrhage. In the other mice treated with $40 \mathrm{~nm}$ AgNPs, the hepatic lesions were not observed and gall bladder lesions were milder, usually consistent with mural hyperemia and/or edema. Mice treated with $100 \mathrm{~nm}$ AgNPs had only occasional and mild gall bladder mural hyperemia and/or edema. No relevant pathological changes were observed in the lung, kidney and brain of AgNP-treated mice, and in all the examined organs of control mice.

A completely different pathological scenario was observed after administration of AgAc. Hepatobiliary lesions were not observed, whereas a marked acute renal tubular necrosis and apoptosis with intraluminal accumulation of hyaline casts was found in all treated mice. Presence of renal lesions, associated with identification of silver in the affected renal tubules and relevant silver concentrations in the kidney of AgAc-treated mice indicates that dissolved silver ions resulted in an increased renal silver distribution compared to AgNPs, and that renal lesions were likely secondary to the renal excretion of silver.

Although liver is considered one of the most important target organs for AgNPs, given its capacity of AgNP accumulation and its role in biliary excretion of AgNPs [49], so 

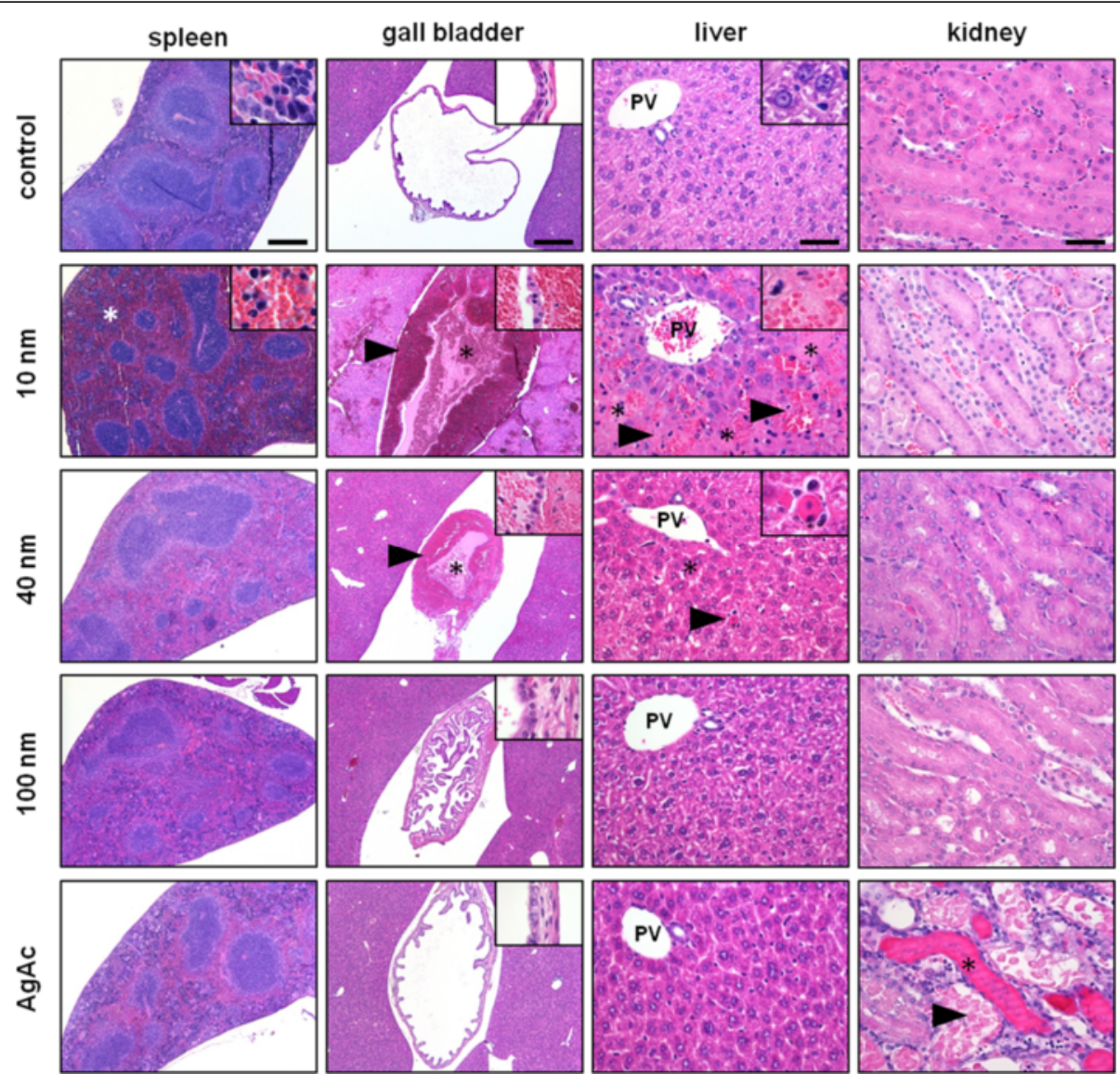

Fig. 6 Histological evaluation of adverse effects after single IV administration of AgNPs and AgAc in mice. Representative images of spleen (scale bar = $500 \mu \mathrm{m})$, gall bladder (scale bar $=500 \mu \mathrm{m})$, liver $(\mathrm{scale} b a r=50 \mu \mathrm{m})$, and kidney (scale bar $=50 \mu \mathrm{m})$ from vehicle- $(\mathrm{control}), \mathrm{AgNP}(10 \mathrm{~nm}, 40 \mathrm{~nm}, 100 \mathrm{~nm})$, and AgAc-treated mice. No relevant changes were present in the examined organs of control mice. In the spleen, a severe hyperemia of the red pulp was present in $10 \mathrm{~nm}$-treated mice $\left(^{*}\right)$. In the gall bladder, severe intraluminal (*) and mural (arrowhead) hemorrhages were found in $10 \mathrm{~nm}$ AgNPs-treated mice, and in a single mouse treated with $40 \mathrm{~nm}$ AgNPs, while in $100 \mathrm{~nm}$-treated mice only mild mural edema and hyperemia were occasionally evident. In the liver, in $10 \mathrm{~nm}$ AgNP-treated mice marked midzonal hepatocellular necrosis (*) and hemorrhages (arrowhead) were present, while in $40 \mathrm{~nm}$-treated mice only occasional single cell necrosis (arrowhead, and inset) and early signs of coagulative periportal necrosis $\left(^{*}\right)$ were found (PV = portal vein). In the kidney, in AgAc-treated mice marked tubular necrosis (arrowhead) with intraluminal hyaline casts $\left(^{*}\right)$ were present

Table 6 Prevalence of histopathological lesions in mice following IV exposure to $10 \mathrm{mg}$ silver/kg. Data are expressed as number of mice with lesions/total number of examined mice per group (\%)

\begin{tabular}{|c|c|c|c|c|c|c|}
\hline Group & Spleen & Liver & Gall bladder & Lung & Kidney & Brain \\
\hline Control & $1 / 3(33 \%)$ & 0/3 (0 \%) & 0/3 (0 \%) & 0/3 (0 \%) & 0/3 (0 \%) & $0 / 3(0 \%)$ \\
\hline 10 nm AgNP-CT & 3/3 (100\%) & 3/3 (100 \%) & $3 / 3(100 \%)$ & 0/3 (0 \%) & 0/3 (0 \%) & $0 / 3(0 \%)$ \\
\hline 10 nm AgNP-PVP & 3/3 (100\%) & 3/3 (100 \%) & 3/3 (100 \%) & 0/3 (0 \%) & 0/3 (0 \%) & $0 / 3(0 \%)$ \\
\hline 40 nm AgNP-CT & $3 / 3(100 \%)$ & 1/3 (33 \%) & $2 / 3(67 \%)$ & 0/3 (0 \%) & 0/3 (0 \%) & 0/3 (0 \%) \\
\hline 40 nm AgNP-PVP & $2 / 3(67 \%)$ & 0/3 (0 \%) & 1/3 (33\%) & 0/3 (0 \%) & 0/3 (0 \%) & $0 / 3(0 \%)$ \\
\hline 100 nm AgNP-CT & 1/3 (33 \%) & 0/3 (0 \%) & $2 / 3(67 \%)$ & 0/3 (0 \%) & 0/3 (0 \%) & $0 / 3(0 \%)$ \\
\hline 100 nm AgNP-PVP & 1/3 (33\%) & 0/3 (0 \%) & 0/3 (0 \%) & 0/3 (0 \%) & 0/3 (0 \%) & $0 / 3(0 \%)$ \\
\hline $\mathrm{AgAc}$ & 0/3 (0 \%) & 0/3 (0 \%) & 0/3 (0 \%) & 0/3 (0 \%) & 3/3 (100 \%) & $0 / 3(0 \%)$ \\
\hline
\end{tabular}


Table 7 Grading of most relevant histopathological lesions in mice after IV administration of $10 \mathrm{mg}$ silver/kg. Results are expressed as median score per group (range) $(n=3)$

\begin{tabular}{|c|c|c|c|c|c|c|}
\hline \multirow[t]{2}{*}{ Group } & \multicolumn{4}{|l|}{ Hepatobiliary tract } & \multirow{2}{*}{$\begin{array}{l}\text { Spleen } \\
\text { Red pulp } \\
\text { hyperemia }\end{array}$} & \multirow{2}{*}{$\begin{array}{l}\text { Kidney } \\
\text { Tubular } \\
\text { necrosis }\end{array}$} \\
\hline & $\begin{array}{l}\text { Hepatocellular necrosis and } \\
\text { hemorrhage }\end{array}$ & $\begin{array}{l}\text { Peribiliary } \\
\text { hemorrhage }\end{array}$ & $\begin{array}{l}\text { Portal vein endothelial } \\
\text { damage }\end{array}$ & $\begin{array}{l}\text { Gall bladder } \\
\text { hemorrhage }\end{array}$ & & \\
\hline Control & $0(0-0)$ & $0(0-0)$ & $0(0-0)$ & $0(0-0)$ & $1(0-2)$ & $0(0-0)$ \\
\hline $\begin{array}{l}10 \text { nm AgNP- } \\
C T\end{array}$ & $4(3-4)$ & $2(1-4)$ & $1(0-4)$ & $2(2-4)$ & $2(2-3)$ & $0(0-0)$ \\
\hline $\begin{array}{l}10 \mathrm{~nm} \text { AgNP- } \\
\text { PVP }\end{array}$ & $4(2-4)$ & $2(1-4)$ & $2(0-4)$ & $2(1-4)$ & $3(3-4)$ & $0(0-0)$ \\
\hline $\begin{array}{l}40 \mathrm{~nm} \text { AgNP- } \\
\mathrm{CT}\end{array}$ & $0(0-1)$ & $0(0-1)$ & $0(0-0)$ & $1(1-4)$ & $2(2-3)$ & $0(0-0)$ \\
\hline $\begin{array}{l}40 \mathrm{~nm} \text { AgNP- } \\
\text { PVP }\end{array}$ & $0(0-0)$ & $0(0-0)$ & $0(0-0)$ & $0(0-1)$ & $2(1-2)$ & $0(0-0)$ \\
\hline $\begin{array}{l}100 \mathrm{~nm} \\
\text { AgNP-CT }\end{array}$ & $0(0-0)$ & $0(0-0)$ & $0(0-0)$ & $1(0-1)$ & $0(0-1)$ & $0(0-0)$ \\
\hline $\begin{array}{l}100 \mathrm{~nm} \\
\text { AgNP-PVP }\end{array}$ & $0(0-0)$ & $0(0-0)$ & $0(0-0)$ & $0(0-0)$ & $1(0-2)$ & $0(0-0)$ \\
\hline $\mathrm{AgAc}$ & $0(0-0)$ & $0(0-0)$ & $0(0-0)$ & $0(0-0)$ & $0(0-0)$ & $4(3-4)$ \\
\hline
\end{tabular}

far hepatotoxic effects of AgNPs have been inconstantly demonstrated in in vivo studies, either after IV, oral, or inhalation exposure to AgNPs. In particular, hepatotoxicity was generally recognized through changes in the blood biochemical parameters of liver function (such as ALT, AST, ALP, and cholesterol) $[16,17,23,58]$, while only occasionally mild histopathological changes were reported, such as biliary hyperplasia, fibrosis, hepatocellular vacuolar degeneration, and rarely necrosis $[15,16,22]$. The lack of overt hepatic histopathological lesions in previous studies that used small-sized particles could be related to a poor dispersion of AgNPs in the administered suspensions [22], since agglomeration of particles can affect bioavailability by reducing the rate of degradation or cell uptake [8]. According to our characterization of AgNPs, we administered well-dispersed $10 \mathrm{~nm}$-sized particles. Another aspect is that most of earlier in vivo studies of distribution and toxicity of AgNPs have been performed in rats and not in mice. Further investigation should be performed in order to assess whether there is a different sensitivity between these two species.

In addition to the severity of the hepatic lesions found in mice treated with $10 \mathrm{~nm}$ AgNPs, also the pattern of hepatocellular necrosis observed is very unusual. Midzonal necrosis is the least common histologic pattern of hepatocellular necrosis following exposure to hepatotoxicants [59]. Because hepatocytes are extremely variable in their metabolic capacity and oxygen tension, midzonal necrosis of hepatocytes is presumably dictated by an unique susceptibility of these hepatocytes based on their location within the hepatic lobule [60]. The hemorrhage observed in the gall bladder of mice treated with $10 \mathrm{~nm}$ AgNPs and occasionally in mice treated with $40 \mathrm{~nm}$ AgNPs is another very unusual finding. We can speculate that gall bladder mural hemorrhage, as well as portal peribiliary hemorrhages, could be the result of endothelial damage secondary to a massive elimination of AgNPs in the bile, which is considered the main route of silver excretion following IV administration of AgNPs [31, 50]. The hypothesis of particle-induced endothelial damage is further corroborated by the presence of endothelial damage found in the intrahepatic branches of portal veins that may have occurred after intestinal re-absorption of AgNPs excreted in the bile. Another concurrent factor in the pathogenesis of gall bladder hemorrhage could be the anti-platelet properties of AgNPs that may have impaired a prompt clotting response [61].

In this study relevant size-dependent adverse effects were observed $24 \mathrm{~h}$ after IV administration of AgNPs in mice. First of all, and differently from previous studies where AgNPs were administered IV (up to a dose of $120 \mathrm{mg} / \mathrm{kg} \mathrm{bw})[22,23,30,31,50]$, mortality was observed in 2 out of 6 mice treated with the smallest particles (10 nm AgNPs), regardless of the coating. The most striking finding was the marked hepatotoxicity demonstrated by $10 \mathrm{~nm}$ AgNPs (both CT and PVP-coated), associated with a massive hemorrhage of the gall bladder. These lesions (in particular the hemorrhage) were especially severe in the two mice found dead, and can thus be regarded as the most likely cause of death. Of note, administration of AgNPs of different sizes and silver acetate resulted in similar liver content of total silver (as determined by ICPMS), indicating that hepatobiliary toxicity induced by $10 \mathrm{~nm}$ AgNPs was not related to the mass of silver contained in the liver, but rather it was imputable to their small size. Size-dependent toxicity of AgNP was previously demonstrated in in vitro $[11,13,14,36]$, as well as in in vivo studies using the respiratory route of 
administration [32, 33]. Our results further support the importance of nanoparticle size for AgNP toxicity in vivo. Release of silver ions following oxidation of particle surface after administration of AgNPs is believed to constitute the major mechanism contributing to AgNP toxicity and since dissolution increases with decreasing size of AgNPs [33], this appears to be the determinant of the enhanced toxicity of smaller AgNPs compared to larger ones. The most obvious explanation for increased dissolution of smaller particles, compared to an equivalent mass concentrations of larger particles, is their higher number (in this study, the number of administered $10 \mathrm{~nm}$ AgNPs was about 100 fold greater compared to $40 \mathrm{~nm}$ AgNPs) and consequent larger surface area per unit mass. The results of our study however demonstrated that systemic availability of silver ions is not responsible for the in vivo hepatobiliary toxicity observed in mice treated with $10 \mathrm{~nm}$ AgNPs, because dissolution of $10 \mathrm{~nm}$ AgNPs in mouse serum was very low $(0.005 \%)$ and administration of AgAc resulted in a distinct target organ of toxicity (kidney instead of hepatobiliary system). Cell-type-dependent toxicity of silver ions and AgNPs was previously demonstrated in in vitro studies. Furthermore, recent in vitro studies demonstrated that toxicity of AgNPs rather than being caused by silver ions liberated in the culture medium is actually dependent on their intracellular release $[35,62,63]$. According to the recently proposed general mechanism for toxicity of metal-containing nanoparticles, the so-called "Lysosome-Enhanced Trojan Horse effect", toxicity of these particles occurs after cellular uptake by endocytosis and it is mediated by enhanced intracellular release of ions secondary to the acidic corrosion within lysosomes [62]. Increased toxicity of smaller AgNPs is then explained by their increased number and reactive surface area, resulting in increased intracellular release of silver ions. The fact that the entry of AgNPs into cells is size-dependent contribute to further enhance the toxic potential of small particles, owing to their higher bioavailability to cells $[11,13,14,35]$.

In our study, coating of AgNPs with CT and PVP did not have a detectable effect on toxicity indicating that particle size is more important than coating to predict potential adverse effects of silver nanoparticles, at least for the coatings tested herein. Coatingdependent toxic effects were demonstrated in vitro $[9,10]$, and only in the lungs in vivo $[32,33]$. It can be speculated that in in vivo studies, including ours, coating has a minor effect, if any, as a consequence of the formation of a corona after the adsorption of proteins (and other biomolecules) on the surface of particles once they enter in contact with biological fluids [28]. The protein corona might mask the effect of the different particle coatings that is evident in in vitro studies. This is in agreement with the recent view that to predict the biological behavior of nanoparticles the fingerprinting of the protein corona is more accurate than the sole characterization of their physicochemical properties, since the protein corona confers to nanoparticles a 'biological identity' that is strongly dependent but distinct from its 'synthetic identity' [64, 65].

\section{Conclusions}

With this study, the influence of two distinct nanoparticle properties, size and coating, was comprehensively investigated in an in vivo model. We observed that tissue distribution and toxic effects of AgNPs in mice after IV administration are strongly size-dependent, while coating (CT or PVP) did not have a sizeable impact on tissue distribution and toxicity. Overall, the smallest $(10 \mathrm{~nm})$ particles resulted in higher silver tissue distribution and caused overt acute adverse effects (centered on the hepatobiliary tract) compared to the larger ones (40 and $100 \mathrm{~nm})$. Overall, these results suggest that in the safety assessment of silver particles the effect of size has to be carefully considered, with a focus on small particles $(\leq 10 \mathrm{~nm})$. Comparison with AgAc revealed a distinct pattern of tissue distribution and toxicity between AgNP and silver ions, indicating that the in vivo effects of AgNPs are not attributable merely to the in vivo release of silver ions in circulating blood but are strictly related to the nanoparticulate form.

\section{Methods}

\section{Characterization of silver nanoparticles}

Suspensions of BioPure ${ }^{\mathrm{Tx}}$ Silver Nanoparticles (AgNPs) of 10, 40 and $100 \mathrm{~nm}$ in size, coated with either citrate (CT) or polyvinylpyrrolidone (PVP), were purchased from NanoComposix (San Diego, USA). All the suspensions were supplied at a concentration of about $1.0 \mathrm{mg} / \mathrm{ml}$. BioPure ${ }^{\mathrm{Tw}}$ AgNPs were chosen because they were guaranteed to be sterile and with an endotoxin level lower or equal to $2.5 \mathrm{EU} / \mathrm{ml}$. The suspending solvents of CT- and PVP-coated AgNPs were $2.0 \mathrm{mM}$ sodium citrate and Milli-Q water (Millipore), respectively. For particle characterization, the CT and PVP-coated AgNPs were diluted with $2.0 \mathrm{mM}$ sodium citrate (cod. W302600, Sigma-Aldrich) buffer and Milli-Q water, respectively. When necessary, samples were sonicated (Elmasonic $S$ $30 \mathrm{H}$ ) for up to $30 \mathrm{~s}$, in accordance with the manufacturer's instructions. In order to prevent contamination, measurements were run using disposable plastic cuvettes. The AgNPs were tested immediately after their delivery and in vivo experiments were run in the following week. In the meanwhile, the AgNPs were stored at $+4{ }^{\circ} \mathrm{C}$, according to manufacturer's instructions. 


\section{Dynamic Light Scattering (DLS)}

The actual size of AgNPs in dispersion was measured by DLS. Measurements were performed with a Malvern Zetasizer Nano ZS90 instrument operating with a light source wavelength of $532 \mathrm{~nm}$ and a fixed scattering angle of $90^{\circ}$. All the nanoparticles were diluted 1:100 with the exception of $10 \mathrm{~nm}$-sized AgNPs. Indeed, due to their small size, the $10 \mathrm{~nm}$ AgNPs presented increased absorption and lower scattering intensity compared to $40 \mathrm{~nm}$ and $100 \mathrm{~nm}$ AgNPs. Accordingly, the $10 \mathrm{~nm}$ AgNPs were diluted 1:50. All measurements were run at room temperature for at least three times.

\section{UV-Visible (UV-Vis) Spectrophotometry}

The UV-Vis spectra were acquired in the $300-800 \mathrm{~nm}$ range using a DU730 Beckman Coulter Spectrophotometer. All the nanoparticles were diluted 1:100 with the exception of $10 \mathrm{~nm}$ AgNPs, which were diluted 1:200 because of their increased UV-Vis absorbance with respect to larger nanoparticles. All measurements were run at room temperature for at least three times.

\section{Transmission Electron Microscopy (TEM)}

Formvar coated copper TEM grids (cod. PE1GC300, Pelco) were pre-treated with $20 \mu \mathrm{l}$ of poly-L-lysine $0.01 \%(\mathrm{w} / \mathrm{v})$ (Sigma Aldrich) for $15 \mathrm{~min}$. After washing twice with MilliQ water, $3 \mu \mathrm{l}$ of AgNPs suspensions were deposited onto the grid for $5 \mathrm{~min}$ and then rinsed with $3 \mu \mathrm{l}$ of 2-propanol (Sigma Aldrich). According to the manufacturer's advice, 100 and $40 \mathrm{~nm}$ AgNPs were used at the concentration of $1.0 \mathrm{mg} / \mathrm{ml}$, while $10 \mathrm{~nm} \mathrm{AgNPs}$ were diluted up to $0.1 \mathrm{mg} / \mathrm{ml}$ before use. The grids were allowed to dry overnight at room temperature in a covered crystallizing dish. TEM (FEI Tecnai G2, Eindhoven) images were analyzed with the ImageJ software (http:// imagej.nih.gov/ij/) to obtain the nanoparticles dimensional distribution. In particular, small objects due to background and overlapping nanoparticles were omitted by using proper cut-off filters and Feret diameter (intended as the larger diameter of the NP projection) was used to evaluate the size of the particles. For each sample, a minimum of about 250 nanoparticles was considered.

\section{Dissolution study}

CT-coated particles were selected for this investigation given the higher stability and lower dissolution generally showed by PVP-coated AgNPs [66, 67]. Dissolution of CT-coated AgNPs of 10, 40 and $100 \mathrm{~nm}$ was ascertained by ultrafiltration, using a PES spin filter membrane (Vivaspin 500, 3 kDa MWCO, Sartorius, Göttingen, Germany) and centrifugation at $15000 \mathrm{~g}$ for $20 \mathrm{~min}$, followed by quantification of silver in the filtrates. The concentration of ionic silver was measured both in the
AgNPs stock suspensions and in conditions simulating AgNPs interaction with biological fluids. For the latter purpose, each stock suspension was spiked to mouse serum (Euroclone, Milan, Italy) in order to provide the mass concentration of AgNPs of a single dose of $10 \mathrm{mg} /$ $\mathrm{kg}$ bw, which approximately corresponded to a 1:5 dilution (v/v) of the original AgNPs suspension. Spiked samples and serum blank were prepared in triplicate and incubated at $37^{\circ} \mathrm{C}$ under agitation for 5, 10, $60 \mathrm{~min}$ and $24 \mathrm{~h}$. Ionic silver was assessed for each timepoint. For ICP-MS determination of ionic silver, filtrates (prepared in triplicate) were vigorously shaken before further dilution and analysis as described in the section "Determination of silver". In addition to ionic silver, each stock suspension of CT-coated AgNPs was characterized in terms of total silver concentration and the results for ionic silver were expressed as percentages of total silver $(\mathrm{AgNPs}+\mathrm{Ag}+)$. Samples for total silver determinations were prepared in triplicate by dilution with acidified $\left(\mathrm{HNO}_{3}\right)$ water as necessary. In order to establish possible sources of bias from the filtration membrane, procedural blanks were run in parallel and the recovery of ionic silver $(10 \mu \mathrm{g} / \mathrm{L})$ from the filtration unit was assessed. No silver was detected in the procedural blanks and the average recovery of ionic silver was found to be $102.6 \pm$ $3.8 \%$, showing absence of silver release/adsorption during filtration.

\section{Animals}

Male CD-1(ICR) mice of $4-5$ weeks were purchased from Charles River (Calco, Italy). They were acclimated to the environment for a week prior to the initiation of the study, with free access to water and a standard pellet diet ad libitum. The environmental conditions were set at a temperature of $22 \pm 2{ }^{\circ} \mathrm{C}$, relative humidity of $55 \pm$ $10 \%$ and a $12 \mathrm{~h} \mathrm{light/dark} \mathrm{cycle.}$

\section{Experimental design}

Mice were randomly assigned to groups of treatments. The mice were intravenously (IV) injected into the lateral tail vein with AgNPs of different sizes $(10 \mathrm{~nm}, 40 \mathrm{~nm}$, $100 \mathrm{~nm}$ ), either CT- or PVP-coated, at a single dose of $10 \mathrm{mg} / \mathrm{kg}$ body weight (bw), and with AgAc at a single dose of $15.5 \mathrm{mg} / \mathrm{kg}$, corresponding to $10 \mathrm{mg} \mathrm{Ag} / \mathrm{kg}$ bw (3 mice per group). The AgNPs suspensions were administered to animals without any dilution. The control group was treated with sterile water for injection. Immediately after the treatment and the following hours, the general health and behavior of mice were monitored. The body weight of each mouse was measured before treatment and at sacrifice. Mice were euthanized $24 \mathrm{~h}$ after the treatment. The experiment was approved by an independent Ethical Committee on Animal Experimentation (Ethical Committee of the University of Milan, Opinion no. 81/14) 
and was performed in accordance with the Italian Laws (D.L.vo 116/92 and following additions), which enforce EU 86/609 Directive.

\section{Sampling}

At $24 \mathrm{~h}$ after IV administration mice were euthanized by carbon dioxide inhalation. After drawing blood from the heart, mice underwent complete necropsy. Blood, liver, spleen, kidneys, lungs, and brain were collected for silver quantification and histopathological examination. The organ weight was measured and relative organ weights (\%) were calculated as wet organ weight/total body weight. For quantification of silver, blood and a portion of the collected organs were stored at $-80{ }^{\circ} \mathrm{C}$ for later analysis.

\section{Determination of silver \\ Chemicals}

Ultrapure deionized water obtained by a Milli-Q Element System (Millipore, Molsheim, France), ultrapure grade nitric acid (67-69 \% v/v) (Carlo Erba Reagenti, Rodano, Italy), ultrapure grade hydrochloric acid (32-35 \% v/v) (Romil Ltd, Cambridge, UK) and ultrapure grade hydrogen peroxide (30 \% v/v) (Merck, Darmstadt, Germany) were used throughout. For ICP-MS measurements, silver calibrants and rhodium solutions used were obtained from standard certified solutions of $1 \mathrm{mg} / \mathrm{ml}$ (High Purity Standard, Charleston, $\mathrm{SC}$ ) by dilution with acidified ( $\mathrm{HNO} 3$ and $\mathrm{HCl}$ ) water, as necessary.

\section{Determination of total silver content}

Total silver concentrations were determined in organs and whole blood by means of a triple quadrupole inductively coupled plasma mass spectrometer (ICP-MS). A 8800 ICPQQQ spectrometer (Agilent Technologies, Japan, Tokio) equipped with an autosampler, a peristaltic pump, a MicroMist glass concentric nebuliser, and operated at a RF power of $1550 \mathrm{~W}$, was used. All sample manipulations were carried out in clean room conditions under a laminar flow box (Spetec GmbH, Erding, Germany). Before ICP-MS measurements, whole organs and blood were placed in Falcon tubes and pre-digested for $5 \mathrm{~h}$ at room temperature with 2-4 $\mathrm{ml} \mathrm{HNO}_{3}$, depending on the organ weight. After adding $1 \mathrm{ml} \mathrm{H}_{2} \mathrm{O}_{2}$, samples were digested in a microwave system (Milestone Ethos $\mathrm{E}$ microwave labstation, FKV, Bergamo, Italy) at $90{ }^{\circ} \mathrm{C}$ for $8 \mathrm{~h}$, maximum power $800 \mathrm{~W}$. After cooling, the digests were diluted by adding $\mathrm{HCl}$ (final concentration $3.0 \mathrm{M}$ ) to promote the formation of soluble silver complexes and prevent the precipitation of insoluble $\mathrm{Ag}^{+}$salts. Prior to analysis the digests were highly diluted with $0.1 \% \mathrm{HNO}_{3}$ and the appropriate amount of $\mathrm{HCl}$ so as to maintain the silver in complexed form. Measurements were carried out on ${ }^{107} \mathrm{Ag}$ and ${ }^{103} \mathrm{Rh}$, as internal standard, by the method of external calibration. The method detection limit ranged from 0.4 to $0.7 \mu \mathrm{g} / \mathrm{kg}$, depending on the tissue, and was $0.09 \mu \mathrm{g} / \mathrm{l}$ for blood.

\section{Analytical quality control}

Trueness of ICP-MS measurements was assessed by analysing the certified reference material SRM 1577c Bovine Liver (NIST, Gaithersburg, MD, USA), with a certified value for silver of $5.9 \pm 1.6 \mu \mathrm{g} / \mathrm{kg}$ and the control material Seronorm ${ }^{\text {Tx }}$ Trace Elements Whole Blood L-1 (SERO AS, Billingstad, Norway) with a indicative value for silver of $185 \pm 10 \mathrm{ng} / \mathrm{l}$, both included in every analytical batch. The average determined silver concentrations were $6.0 \pm$ $0.5 \mu \mathrm{g} / \mathrm{kg}(n=6)$ and $179 \pm 2 \mathrm{ng} / \mathrm{l}(n=6)$ for the liverbased and the blood-based materials, respectively, in good agreement with the reference values. The trueness of determinations was also assessed through spikes of known amounts of silver in tissues and blood before sample dissolution, giving recoveries within the range of 90-100 \% with no appreciable differences between sample types.

\section{Histopathological examination}

For histological examination, liver (median lobe including the gall bladder), spleen (apical portion), kidney (half of the right kidney), lung (left lobe), brain (half brain, cut along the sagittal plane) were fixed in $10 \%$ neutral buffered formalin for at least $48 \mathrm{~h}$ at room temperature, routinely processed for paraffin embedding, sectioned at $4 \mu \mathrm{m}$ thickness, stained with hematoxylin-eosin (H\&E), and evaluated under a light microscope. Grading of histopathological lesions in the examined organs was performed as follows: $0=$ absence of lesions; $1=$ minimal lesions; 2 =mild lesions; 3 = moderate lesions; $4=$ severe lesions.

To analyze the tissue distribution and localization of silver, autometallography (AMG) [42] and immunofluorescence were performed on serial sections. After AMG staining, sections were counterstained with safranin $O$ and evaluated under a light microscope for the identification of tissue and cellular localization of silver, visible as black granular pigment. For immunofluorescence, liver sections were immunostained with rabbit monoclonal anti-IBA1 antibody (Wako Chemicals Richmond, VA, USA, cat. No. 019-19741), a pan-macrophage marker [68]. Secondary antibody, Alexa Fluor 555 F(ab')2 Fragment of Goat Anti-Rabbit IgG $(\mathrm{H}+\mathrm{L})$ (Life Technologies Europe BV, Monza, Italy, cat. No. A-21430) was then added. Immunofluorescently labeled sections were acquired with the Leica TCS SP5 confocal microscope (Leica Microsystems GmbH, Wetzlar, Germany). The Alexa555 fluorophore was excited with the $561 \mathrm{~nm}$ laser line and the emitted fluorescence (570-700 nm) acquired with a 63x/ 1.4 oil immersion objective (Leica Microsystems $\mathrm{GmbH}$ ). Nuclei were visualized by DAPI staining (405 $\mathrm{nm}$ laser line 
excitation, 415-500 $\mathrm{nm}$ acquisition window). Silver aggregates were visualized by reflection of light at $561 \mathrm{~nm}$ [24].

\section{Statistical analysis}

Data were analyzed using Graph Pad Prism version 5.0 (GraphPad Software, San Diego, CA). For TEM, paired samples $t$-test was performed. Since the number of data (weights and silver concentrations) obtained from in vivo experiments was small, nonparametric tests (Kruskal-Wallis and Mann-Whitney $U$ test) were used to detect differences between groups. The $P$-values $<0.05$ were considered statistically significant. Data were additionally explored by Principal Component Analysis, in order to understand the relationships among variables and their effect on data distribution.

\section{Additional file}

Additional file 1: Table S1. Body weight gain and relative organ weight (\%) after IV administration of differently coated AgNPs. Table S2. Silver tissue concentration determined by ICP-MS after IV administration of AgNPs and AgAc. Figure S1. Silver tissue concentration after IV administration of differently coated AgNPs and AgAc. Figure S2. Principal component analysis of silver tissue concentration data. Figure S3. Histology of spleen and liver after IV administration of $10 \mathrm{mg} \mathrm{Ag/Kg}$ in mice. Figure S4. Histology of liver from mice treated with $10 \mathrm{~nm}$ AgNPs. (PDF $728 \mathrm{~kb}$ )

\section{Abbreviations \\ AgAc: silver acetate; AgNP: silver nanoparticle; AMG: autometallography; bw: body weight; CT: sodium citrate; DLS: dynamic light scattering; H\&E: hematoxylin and eosin; ICP-MS: inductively coupled plasma mass spectroscopy; PVP: polyvinylpyrrolidone; TEM: transmission electron microscopy; UV-Vis: UV-visible.}

\section{Competing interests}

The authors declare that they have no competing interests.

\section{Authors' contributions}

CR conceived and designed the study, performed the histopathological analysis, analyzed and interpreted the data, and drafted the manuscript. MDM participated in the design of the study, conducted the animal exposures, performed the histochemical stainings, participated in the data analysis, and drafted the manuscript. SB conducted the animal exposures. SA and CC carried out the particle characterization, data analysis, and drafted the manuscript. SM performed the statistical analysis. FA, MDA, AR conducted the dissolution study, the ICP-MS measurements, and related data analysis. FC planned and supervised the dissolution study and ICP-MS characterization of tissue distribution, and critically revised the manuscript. $\mathrm{CL}$ was the project leader, and critically revised the manuscript. PM critically revised the manuscript. ES participated in the planning of the study, supervised the histopathological analysis, and critically revised the manuscript. All authors read and approved the final manuscript.

\section{Acknowledgements}

This research was supported by Fondazione Cariplo for the project "Toxicology of chronic exposure to engineered silver nanoparticles", under the 2011 call"Nanoparticles, nanotechnologies and ultrafine particles". We are grateful to S. Rodighiero for assistance in the analysis at confocal microscope, D. Marchesi for assistance in TEM imaging, and M. Losa for technical histological support.

\section{Author details}

${ }^{1}$ Fondazione Filarete, 20139 Milan, Italy. ${ }^{2}$ Dipartimento di Scienze Veterinarie e Sanità Pubblica (DIVET), Università degli Studi di Milano, 20133 Milan, Italy. ${ }^{3}$ Dipartimento di Fisica, Università degli Studi di Milano, 20133 Milan, Italy.
${ }^{4}$ Department of Food Safety and Veterinary Public Health, Istituto Superiore di Sanità - National Health Institute, 00161 Rome, Italy. ${ }^{5}$ Centro Interdisciplinare Materiali e Interfacce Nanostrutturati (CIMAINA), Università degli Studi di Milano, 20133 Milan, Italy.

Received: 29 June 2015 Accepted: 22 February 2016

Published online: 29 February 2016

\section{References}

1. Völker C, Oetken M, Oehlmann J. The biological effects and possible modes of action of nanosilver. Rev Environ Contam Toxicol. 2013;223:81-106.

2. Ahamed M, Alsalhi MS, Siddiqui MK. Silver nanoparticle applications and human health. Clin Chim Acta. 2010;411:1841-8.

3. The Project on Emerging Nanotechnologies. Consumer Products Inventory. 2015. http://www.nanotechproject.org/cpi. Accessed 15 April 2015.

4. Schäfer B, Brocke JV, Epp A, Götz M, Herzberg F, Kneuer C, et al. State of the art in human risk assessment of silver compounds in consumer products: a conference report on silver and nanosilver held at the BfR in 2012. Arch Toxicol. 2013;87:2249-62.

5. Schluesener JK, Schluesener HJ. Nanosilver: application and novel aspects of toxicology. Arch Toxicol. 2013;87:569-76.

6. Mijnendonckx K, Leys N, Mahillon J, Silver S, Van Houdt R. Antimicrobial silver: uses, toxicity and potential for resistance. Biometals. 2013;26:609-21.

7. Morones JR, Elechiquerra JL, Camacho A, Holt K, Kouri JB, Ramirez JT, et al. The bactericidal effect of silver nanoparticles. Nanotechnology. 2005;16:2346-53.

8. Stensberg MC, Wei Q, McLamore ES, Porterfield DM, Wei A, Sepúlveda MS Toxicological studies on silver nanoparticles: challenges and opportunities in assessment, monitoring and imaging. Nanomedicine. 2011;6:879-98.

9. El Badawy AM, Silva RG, Morris B, Scheckel KG, Suidan MT, Tolaymat TM. Surface charge-dependent toxicity of silver nanoparticles. Environ Sci Technol. 2011:45:283-7.

10. Nguyen KC, Seligy VL, Massarsky A, Moon TW, Rippstein P, Tan J, et al. Comparison of toxicity of uncoated and coated silver nanoparticles. J Phys Conf Ser. 2013;429:012025

11. Carlson C, Hussain SM, Schrand AM, Braydich-Stolle LK, Hess KL, Jones RL, et al. Unique cellular interaction of silver nanoparticles: size-dependent generation of reactive oxygen species. J Phys Chem B. 2008;112:13608-19.

12. Hsin YH, Chen CF, Huang S, Shih TS, Lai PS, Chueh PJ. The apoptotic effect of nanosilver is mediated by a ROS- and JNK-dependent mechanism involving the mitochondrial pathway in NIH3T3 cells. Toxicol Lett. 2008;179:130-9.

13. Kim TH, Kim M, Park HS, Shin US, Gong MS, Kim HW. Size-dependent cellular toxicity of silver nanoparticles. J Biomed Mater Res A. 2012;100: 1033-43.

14. Park MV, Neigh AM, Vermeulen JP, de la Fonteyne $L$, Verharen HW, Briedé $J$, et al. The effect of particle size on the cytotoxicity, inflammation, developmental toxicity and genotoxicity of silver nanoparticles. Biomaterials. 2011;32:9810-7.

15. Sung JH, Ji JH, Park JD, Yoon JU, Kim DS, Jeon KS, et al. Subchronic inhalation toxicity of silver nanoparticles. Toxicol Sci. 2009;108:452-61.

16. Kim YS, Song MY, Park JD, Song KS, Ryu HR, Chung YH, et al. Subchronic oral toxicity of silver nanoparticles. Part Fibre Toxicol. 2010;7:20.

17. Park EJ, Bae E, Yi J, Kim Y, Choi K, Lee SH, et al. Repeated-dose toxicity and inflammatory responses in mice by oral administration of silver nanoparticles. Environ Toxicol Pharmacol. 2010;30:162-8.

18. Samberg ME, Oldenburg SJ, Monteiro-Riviere NA. Evaluation of silver nanoparticle toxicity in skin in vivo and keratinocytes in vitro. Environ Health Perspect. 2010;118:407-13.

19. Stebounova LV, Adamcakova-Dodd A, Kim JS, Park H, O'Shaughnessy PT, Grassian $\mathrm{VH}$, et al. Nanosilver induces minimal lung toxicity or inflammation in a subacute murine inhalation model. Part Fibre Toxicol. 2011;8:5.

20. Hadrup N, Loeschner K, Bergström A, Wilcks A, Gao X, Vogel U, et al. Subacute oral toxicity investigation of nanoparticulate and ionic silver in rats. Arch Toxicol. 2012;86:543-51.

21. van der Zande M, Vandebriel RJ, Van Doren E, Kramer E, Herrera Rivera Z, Serrano-Rojero CS, et al. Distribution, elimination, and toxicity of silver nanoparticles and silver ions in rats after 28-day oral exposure. ACS Nano. 2012;6:7427-42.

22. Xue $Y$, Zhang S, Huang Y, Zhang T, Liu X, Hu Y, et al. Acute toxic effects and gender-related biokinetics of silver nanoparticles following an intravenous injection in mice. J Appl Toxicol. 2012;32:890-9. 
23. De Jong WH, Van Der Ven LT, Sleijffers A, Park MV, Jansen EH, Van Loveren H, et al. Systemic and immunotoxicity of silver nanoparticles in an intravenous 28 days repeated dose toxicity study in rats. Biomaterials. 2013;34:8333-43.

24. Gaiser BK, Fernandes TF, Jepson MA, Lead JR, Tyler CR, Baalousha M, et al. Interspecies comparisons on the uptake and toxicity of silver and cerium dioxide nanoparticles. Environ Toxicol Chem. 2012;31:144-54.

25. Korani M, Rezayat SM, Arbabi BS. Sub-chronic dermal toxicity of silver nanoparticles in guinea pig: special emphasis to heart, bone and kidney toxicities. Iran J Pharm Res. 2013;12:511-9.

26. Shahare B, Yashpal M. Toxic effects of repeated oral exposure of silver nanoparticles on small intestine mucosa of mice. Toxicol Mech Methods. 2013;23:161-7

27. Reidy B, Haase A, Luch A, Dawson KA, Lynch I. Mechanisms of silver nanoparticle release, transformation and toxicity: a critical review of current knowledge and recommendations for future studies and applications. Materials. 2013;6:2295-350.

28. Monopoli MP, Aberg C, Salvati A, Dawson KA. Biomolecular coronas provide the biological identity of nanosized materials. Nat Nanotechnol. 2012;7:779-86.

29. Warheit DB. Debunking some misconceptions about nanotoxicology. Nano Lett. 2010;10:4777-82.

30. Lankveld DP, Oomen AG, Krystek P, Neigh A, Troost-de Jong A, Noorlander $\mathrm{CW}$, et al. The kinetics of the tissue distribution of silver nanoparticles of different sizes. Biomaterials. 2010;31:8350-61.

31. Dziendzikowska K, Gromadzka-Ostrowska J, Lankoff A, Oczkowski M, Krawczyńska A, Chwastowska J, et al. Time-dependent biodistribution and excretion of silver nanoparticles in male Wistar rats. J Appl Toxicol. 2012:32:920-8.

32. Wang $X$, Ji Z, Chang CH, Zhang H, Wang M, Liao YP, et al. Use of coated silver nanoparticles to understand the relationship of particle dissolution and bioavailability to cell and lung toxicological potential. Small. 2014;10:385-98.

33. Seiffert J, Hussain F, Wiegman C, Li F, Bey L, Baker W, et al. Pulmonary toxicity of instilled silver nanoparticles: influence of size, coating and rat strain. PLoS One. 2015;10:e0119726.

34. SCENIHR (Scientific Committee on Emerging and Newly Identified Health Risks). Nanosilver: safety, health and environmental effects and role in antimicrobial resistance. 2014. http://ec.europa.eu/health/scientific committees/consultations/public_consultations/scenihr_consultation_17_en. htm. Accessed 15 April 2015.

35. Gliga AR, Skoglund S, Wallinder IO, Fadeel B, Karlsson HL. Size-dependent cytotoxicity of silver nanoparticles in human lung cells: the role of cellular uptake, agglomeration and Ag release. Part Fibre Toxicol. 2014;11:11.

36. Ivask A, Kurvet I, Kasemets K, Blinova I, Aruoja V, Suppi S, et al. Sizedependent toxicity of silver nanoparticles to bacteria, yeast, algae, crustaceans and mammalian cells in vitro. PLoS One. 2014;9:e102108.

37. Noguez C. Surface plasmons on metal nanoparticles: the influence of shape and physical environment. J Phys Chem C. 2007;111:3806-19.

38. Izquierdo-Lorenzo I, Kubackova J, Manchon D, Mosset A, Cottancin E, Sanchez-Cortes S. Linking Ag nanoparticles by aliphatic a, $\omega$-dithiols: a study of the aggregation and formation of interparticle hot spots. J Phys Chem C. 2013;117:16203-12.

39. Shannahan JH, Podila R, Brown JM. A hyperspectral and toxicological analysis of protein corona impact on silver nanoparticle properties, intracellular modifications, and macrophage activation. Int J Nanomedicine. 2015;10:6509-21

40. Bachler G, von Goetz N, Hungerbühler K. A physiologically based pharmacokinetic model for ionic silver and silver nanoparticles. Int J Nanomedicine. 2013;8:3365-82.

41. Loza K, Diendorf J, Sengstock C, Ruiz-Gonzalez L, Gonzalez-Calbet JM, ValletRegi $\mathrm{M}$, et al. The dissolution and biological effects of silver nanoparticles in biological media. J Mater Chem B. 2014;2:1634-43.

42. Su C, Sun Y. Considerations of inductively coupled plasma mass spectrometry techniques for characterizing the dissolution of metal-based nanomaterials in biological tissues. J Anal At Spectrom. 2015;30:1689-705.

43. Utembe W, Potgieter K, Stefaniak AB, Gulumian M. Dissolution and biodurability: Important parameters needed for risk assessment of nanomaterials. Part Fibre Toxicol. 2015;12:11

44. Roe D, Karandikar B, Bonn-Savage N, Gibbins B, Roullet JB. Antimicrobial surface functionalization of plastic catheters by silver nanoparticles. J Antimicrob Chemother. 2008;61:869-76.

45. Rigo C, Ferroni L, Tocco I, Roman M, Munivrana I, Gardin C, et al. Active silver nanoparticles for wound healing. Int J Mol Sci. 2013;14:4817-40.
46. Schrand AM, Braydich-Stollel LK, Schlager JJ, Dai L, Hussain SM. Can silver nanoparticles be useful as potential biological labels? Nanotechnology. 2008;19:235104

47. Wei L, Lu J, Xu H, Patel A, Chen ZS, Chen G. Silver nanoparticles: synthesis, properties, and therapeutic applications. Drug Discov Today. 2015;20:595-601.

48. Loeschner K, Hadrup N, Qvortrup K, Larsen A, Gao X, Vogel U, et al. Distribution of silver in rats following 28 days of repeated oral exposure to silver nanoparticles or silver acetate. Part Fibre Toxicol. 2011;8:18.

49. Kwon JT, Minai-Tehrani A, Hwang SK, Kim JE, Shin JY, Yu KN, et al. Acute pulmonary toxicity and body distribution of inhaled metallic silver nanoparticles. Toxicol Res. 2012;28:25-31.

50. Park K, Park EJ, Chun IK, Choi K, Lee SH, Yoon J, et al. Bioavailability and toxicokinetics of citrate-coated silver nanoparticles in rats. Arch Pharm Res. 2011;34:153-8.

51. Reagan-Shaw S, Nihal M, Ahmad N. Dose translation from animal to human studies revisited. FASEB J. 2008;22:659-61.

52. Sadauskas $E$, Wallin $H$, Stoltenberg M, Vogel U, Doering $P$, Larsen A, et al. Kupffer cells are central in the removal of nanoparticles from the organism. Part Fibre Toxicol. 2007:4:10.

53. Sadauskas E, Danscher G, Stoltenberg M, Vogel U, Larsen A, Wallin H. Protracted elimination of gold nanoparticles from mouse liver. Nanomedicine. 2009:5:162-9.

54. Danscher G, Stoltenberg M. Silver enhancement of quantum dots resulting from (1) metabolism of toxic metals in animals and humans, (2) in vivo, in vitro and immersion created zinc-sulphur/zinc-selenium nanocrystals, (3) metal ions liberated from metal implants and particles. Prog Histochem Cytochem. 2006:41:57-139.

55. Danscher G. Light and electron microscopic localization of silver in biological tissue. Histochemistry. 1981;71:177-86.

56. Matsumura T, Kumakiri M, Ohkawara A, Himeno H, Numata T, Adachi R. Detection of selenium in generalized and localized argyria: report of four cases with X-ray microanalysis. J Dermatol. 1992;19:87-93.

57. Massi D, Santucci M. Human generalized argyria: a submicroscopic and Xray spectroscopic study. Ultrastruct Pathol. 1998;22:47-53.

58. Lee JH, Kim YS, Song KS, Ryu HR, Sung JH, Park JD, et al. Biopersistence of silver nanoparticles in tissues from Sprague-Dawley rats. Part Fibre Toxicol. 2013:10:36.

59. Thoolen B, Maronpot RR, Harada T, Nyska A, Rousseaux C, Nolte T, et al. Proliferative and nonproliferative lesions of the rat and mouse hepatobiliary system. Toxicol Pathol. 2010;38:5S-81S.

60. Haschek WM, Wallig MA, Rousseaux CG. The liver. In: Fundamentals of Toxicologic Pathology. London: Academic; 2010. p. 197-235.

61. Shrivastava S, Bera T, Singh SK, Singh G, Ramachandrarao P, Dash D. Characterization of antiplatelet properties of silver nanoparticles. ACS Nano. 2009:3:1357-64.

62. Sabella S, Carney RP, Brunetti V, Malvindi MA, Al-Juffali N, Vecchio G, et al. A general mechanism for intracellular toxicity of metal-containing nanoparticles. Nanoscale. 2014:6:7052-61.

63. De Matteis V, Malvindi MA, Galeone A, Brunetti V, De Luca E, Kote S, et al. Negligible particle-specific toxicity mechanism of silver nanoparticles: The role of $\mathrm{Ag}(+)$ ion release in the cytosol. Nanomedicine. 2015;11:731-9.

64. Walkey CD, Chan WCW. Understanding and controlling the interaction of nanomaterials with proteins in a physiological environment. Chem Soc Rev. 2012:41:2780-99.

65. Walkey CD, Olsen JB, Song F, Liu R, Guo H, Olsen W, et al. Protein corona fingerprinting predicts the cell association of gold nanoparticles. ACS Nano. 2014:8:2439-55

66. Tejamaya M, Römer I, Merrifield RC, Lead JR. Stability of citrate, PVP, and PEG coated silver nanoparticles in ecotoxicology media. Environ Sci Technol. 2012;46:7011-7.

67. An Huynh K, Chen KL. Aggregation kinetics of citrate and polyvinylpyrrolidone coated silver nanoparticles in monovalent and divalent electrolyte solutions. Environ Sci Technol. 2011;45:5564-71.

68. Rehg JE, Bush D, Ward JM. The utility of immunohistochemistry for the identification of hematopoietic and lymphoid cells in normal tissues and interpretation of proliferative and inflammatory lesions of mice and rats. Toxicol Pathol. 2012;40:345-74. 